\title{
Conservation Agriculture Based Integrated Crop Management Sustains the Maize-Wheat Rotation of North-Western India: Five Years' Impacts on Crops and Water Productivity, Economic Profitability, Sustainable Yield Index and Soil Properties
}

Vijay Pooniya ( $\sim$ vpooniya@gmail.com )

ICAR-Indian Agricultural Research Institute (IARI)

\section{R. R. Zhiipao}

ICAR-Indian Agricultural Research Institute (IARI)

Niraj Biswakarma

ICAR-Indian Agricultural Research Institute (IARI)

Dinesh Kumar

ICAR-Indian Agricultural Research Institute (IARI)

Y. S. Shivay

ICAR-Indian Agricultural Research Institute (IARI)

Subhash Babu

ICAR-Indian Agricultural Research Institute (IARI)

Kajal Das

ICAR-Central Research Institute for Jute and Allied Fibers

A. K. Choudhary

ICAR-Central Potato Research Institute (CPRI)

Karivaradharajan Swarnalakshmi

ICAR-Indian Agricultural Research Institute (IARI)

R.D. Jat

Chaudhary Charan Singh Haryana Agricultural University (CCSHAU)

\section{R. L. Choudhary}

ICAR-Directorate of Rapeseed-Mustard Research

Hardev Ram

ICAR-National Dairy Research Institute

Mukesh Khokhar

ICAR - National Centre for Integrated Pest Management

Ganapati Mukri

ICAR-Indian Agricultural Research Institute (IARI)

\section{K. K. Lakhena}

ICAR-Indian Agricultural Research Institute (IARI)

M. M. Puniya

Agriculture University

Rajkumar Jat

Borlaug Institute for South Asia (BISA)

\section{Muralikrishnan}

ICAR-Indian Agricultural Research Institute (IARI)
A.K. Singh
ICAR-Indian Institute of Maize Research (IIMR)

Achal Lama

ICAR-Indian Agricultural Statistics Research Institute (IASRI) 


\section{Research Article}

Keywords: integrated crop management, ICM5\&6, conservation agriculture, System water productivity

Posted Date: December 6th, 2021

DOI: https://doi.org/10.21203/rs.3.rs-1103288/v1

License: (c) This work is licensed under a Creative Commons Attribution 4.0 International License. Read Full License 


\section{Abstract}

We have evaluated eight different integrated crop management (ICM) modules for five years in a maize-wheat rotation ( $\left.M_{W R}\right)$; wherein,

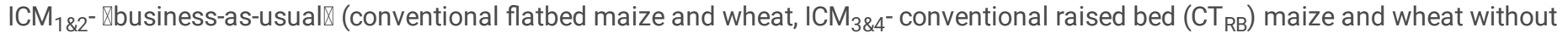
residues, ICM $\mathrm{IC}_{58}$ - conservation agriculture (CA)-based zero till (ZT) flatbed maize and wheat with the residues, and ICM $7 \& 8$ - $C A$-based ZT raised bed maize and wheat with the residues. Results indicated that the $\mathrm{ICM}_{788}$ produced significantly $(\mathrm{p}<0.05)$ the highest maize grain yield (5 years av.) which was 7.8-21.3\% greater than the $\mathrm{ICM}_{1-6}$. However, across years, the $\mathrm{ICM}_{5-8}$ gave statistically similar wheat grain yield, and was 8.4-11.5\% greater than the ICM ${ }_{1-4}$. Similarly, the CA-based residue retained ICM $\mathrm{IC}_{-8}$ modules had given 9.5-14.3\% (5 years av.) greater system yields in terms of maize grain equivalents $\left(\mathrm{M}_{\mathrm{GEY}}\right)$ over the residue removed CT-based ICM $1 \& 4$. System water productivity $\left(\mathrm{S}_{\mathrm{WP}}\right)$ was the highest with $\mathrm{ICM}_{5-8}$, being 10.3-17.8\% higher than the ICM ${ }_{1-4}$. Nevertheless, the highest water use ( $\left.T_{\text {wu}}\right)$ was recorded in the CT flatbed $\left(\mathrm{ICM}_{182}\right), \sim 7 \%$ more than the raised bed and ZT planted crops with or without the residues $\left(\mathrm{ICM}_{4-8}\right)$. Furthermore, the ICM $\mathrm{ICA}_{1-4}$ had produced 9.54\% greater variable production costs compared to the ICM $\mathrm{ICM}_{5-8}$, whereas, the $\mathrm{ICM}_{5-8}$ gave $24.3-27.4 \%$ additional returns than the ICM $I \mathrm{CM}_{1-4}$. Also, different ICM modules caused significant $(p<0.05)$ impacts on the soil properties, such as, organic carbon $\left(\mathrm{S}_{O C}\right)$, microbial biomass carbon $\left(\mathrm{S}_{\mathrm{MBC}}\right)$, dehydrogenase $\left(\mathrm{S}_{\mathrm{DH}}\right)$, alkaline phosphatase $\left(\mathrm{S}_{\mathrm{AP}}\right)$ and urease $\left(\mathrm{U}_{\mathrm{RE}}\right)$ activities. In 0.0-0.15 m soil profile, residue retained CAbased $\left(\mathrm{ICM}_{5-8}\right)$ modules registered a 7.1-14.3\% greater $\mathrm{S}_{\mathrm{OC}}$ and $10.2-17.3 \% \mathrm{~S}_{\mathrm{MBC}}$ than the ICM $\mathrm{IC}_{1-4}$. The sustainable yield index $\left(\mathrm{S}_{\mathrm{YI}}\right)$ of $\mathrm{M}_{\mathrm{WR}}$ was $13.4-18.6 \%$ greater under the $\mathrm{ICM}_{788}$ compared to the ICM $\mathrm{ICM}_{1-4}$. Hence, this study conclude that the adoption of the CA-based residue retained ICMs in the $\mathrm{M}_{\mathrm{WR}}$ could sustain the crop yields, enhance farm profits, save water and improve soil properties of the north-western plan zones of India.

\section{Background}

We have evaluated eight different integrated crop management (ICM) modules for five years in a maize-wheat rotation ( $\left.M_{W R}\right)$; wherein,

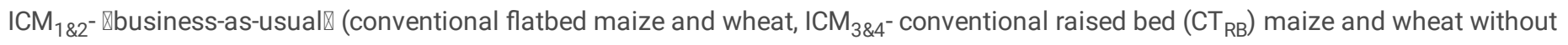
residues, ICM $\mathrm{IC}_{58}$ - conservation agriculture (CA)-based zero till (ZT) flatbed maize and wheat with the residues, and ICM ${ }_{7 \& 8-}$ CA-based ZT raised bed maize and wheat with the residues. Results indicated that the $\mathrm{ICM}_{7 \& 8}$ produced significantly $(\mathrm{p}<0.05)$ the highest maize grain yield (5 years av.) which was 7.8-21.3\% greater than the ICM $1-6$. However, across years, the ICM $\mathrm{IC}_{58}$ gave statistically similar wheat grain yield, and was $8.4-11.5 \%$ greater than the ICM $\mathrm{ICM}_{1-4}$. Similarly, the CA-based residue retained ICM $\mathrm{IC}_{-8}$ modules had given $9.5-14.3 \%$ (5 years av.) greater system yields in terms of maize grain equivalents $\left(\mathrm{M}_{\mathrm{GEY}}\right)$ over the residue removed CT-based ICM ${ }_{184}$. System water productivity $\left(\mathrm{S}_{\mathrm{WP}}\right)$ was the highest with $\mathrm{ICM}_{5-8}$, being 10.3-17.8\% higher than the $\mathrm{ICM}_{1-4}$. Nevertheless, the highest water use ( $\left.\mathrm{T}_{\mathrm{Wu}}\right)$ was recorded in the CT flatbed $\left(\mathrm{ICM}_{182}\right), \sim 7 \%$ more than the raised bed and ZT planted crops with or without the residues $\left(\mathrm{ICM}_{4-8}\right)$. Furthermore, the ICM $\mathrm{ICM}_{1-4}$ had produced 9.54\% greater variable production costs compared to the ICM $\mathrm{ICM}_{5-8}$, whereas, the ICM $\mathrm{IC}_{5-8}$ gave $24.3-27.4 \%$ additional returns than the ICM $\mathrm{ICM}_{1-4}$. Also, different ICM modules caused significant $(\mathrm{p}<0.05)$ impacts on the soil properties, such as, organic carbon $\left(\mathrm{S}_{O C}\right)$, microbial biomass carbon $\left(\mathrm{S}_{\mathrm{MBC}}\right)$, dehydrogenase $\left(\mathrm{S}_{\mathrm{DH}}\right)$, alkaline phosphatase $\left(\mathrm{S}_{\mathrm{AP}}\right)$ and urease $\left(\mathrm{U}_{\mathrm{RE}}\right)$ activities. In 0.0-0.15 m soil profile, residue retained CAbased $\left(\mathrm{ICM}_{5-8}\right)$ modules registered a $7.1-14.3 \%$ greater $\mathrm{S}_{\mathrm{OC}}$ and $10.2-17.3 \% \mathrm{~S}_{\mathrm{MBC}}$ than the ICM $\mathrm{I}_{1-4}$. The sustainable yield index $\left(\mathrm{S}_{\mathrm{YI}}\right)$ of $\mathrm{M}_{\mathrm{WR}}$ was $13.4-18.6 \%$ greater under the $\mathrm{ICM}_{788}$ compared to the ICM $\mathrm{ICM}_{1-4}$. Hence, this study conclude that the adoption of the CA-based residue retained ICMs in the $\mathrm{M}_{\mathrm{WR}}$ could sustain the crop yields, enhance farm profits, save water and improve soil properties of the north-western plan zones of India.

Globally, maize (Zea mays L.) is the $3^{\text {rd }}$ most important cereal, and across ecologies, being grown in $~ 155$ nations; called $\llbracket Q u e e n$ of cereals $\square$ (maize), the back bone of American food or a miracle crop. The United State produced $~ 31 \%$ of the maize grains, subsequently China (24\%), Brazil $(8 \%)$ and India $(2.2 \%)^{1,2}$. In India, the maize-wheat rotation $\left(\mathrm{M}_{\mathrm{WR}}\right)$ is the $5^{\text {th }}$ leading cropping rotation, occupying $\sim 2$ million ha in the Indo-Gangetic Plains $\left(I_{G P s}\right)$, the heart land of the rice-wheat rotation $\left(R_{W R}\right)^{3}$. The relatively greater yields of the $R_{W R}$ in the upper $I_{G P s}$ materialized at the costs of the over utilization of the natural resources ${ }^{4,5}$, which caused nutrient imbalances, greater energy use and increased labour demands, weed shift / resistance and more $G_{H G s}$ emissions ${ }^{6,7}$. Further, rice residue burning is one of the realised threats of the $\mathrm{R}_{\mathrm{WR}}$ sustainability, which resulted in the extensive impacts on the losses of soil organic matter $\left(\mathrm{S}_{\mathrm{OM}}\right)$ and nutrients, reduced biodiversity, lowered water and energy efficiency, and of course the declined air quality. In India's capital and other adjoining north Indian cities, the residue burning reduces air quality, with severe impacts on human and animal health ${ }^{8,9}$. Hence, these ruinous factors have given impetus to pursue alternative crops / rotations or to follow the integrated sustainable strategies in the line of UN Sustainable Development Goals, i.e., more environmentally sound and efficient utilizer of resources ${ }^{10,11,12}$. 
The maize adaptability to diverse agro-ecologies or across seasons is unmatched to any other crops. It can be a feasible alternative to the rice in $\mathrm{R}_{\mathrm{WR}}$, and a potential driver for the crop diversification ${ }^{13,14}$. In India, it covers $\sim 9.5$ million hectares with 24.5 million tonnes annual production, and $3^{\text {rd }}$ most important food crop next to rice and wheat ${ }^{2}$. It is consumed in the form of grains, green cobs, sweet corn, baby corn and popcorn, besides its use as animal feed, fodder and raw material for the industrial products such as food (25\%), animal feed (12\%), poultry feed (49\%), starch (12\%), brewery and seed ${ }^{15}$. The intensive tillage with crop establishment accounts $25 \%$ of the total production cost, leading to the reduced net income ${ }^{16}$. Here, the major challenge is to develop the alternative production system that should be climate and resource resilient, and can help to sustain the crop yields in the long-run ${ }^{17}$. Recently, the CA-based crop management, such as no-till or zero-till with residue retention and judicious crop rotations, is gaining more attention with the rising concerns pertaining to the over degradation of the natural resources, to offset the production cost ${ }^{18}$. Both the crops (maize, wheat) could be well fitted, and may prove input responsive in the CA-based practices ${ }^{19,20}$. A great potential exists to raise the yields and sustainability of the maize-wheat rotation ( $\mathrm{M}_{\mathrm{WR}}$ ) further by combining the CA-based production with certain integrated crop management (ICM) practices. Thus, need was felt to find out the best combinations of the ICM practices to accomplish the sustainability of the $\mathrm{M}_{\mathrm{WR}}$. It is reported that these ICM practices can help in the initial crop establishment with greater input efficiency, and open up avenues for CA-based ICMs which could further help in the timely seeding of the both crops, hence may lead to the sustained yields without compromising the degradation of the natural resources.

Recently, the Food and Agriculture Organisation (FAO) has suggested that the ICM is of much significance and relevance than the individual agronomic management approach. The ICM is fundamentally based on the understanding of the interactions between the biology, environment and the land management systems apart from conserving the natural resources and producing the food on an economically viable and sustainable platform ${ }^{21}$. Adoption of the ICM practices significantly improved the crop yields to the tune of $20-30 \%$ in India ${ }^{22}$, and $13.5 \%$ in China ${ }^{23}$ over the farmers' practice, while minimizing the production costs simultaneously ${ }^{24,25}$. In $\mathrm{R}_{\mathrm{WR}}$, a recent long-term study showed the superiority of the ICM-based modules, with $10-13 \%$ greater system yields, saved $8-12 \%$ irrigation water, and gave $19-22 \%$ additional economic returns over the CT-based modules ${ }^{5}$.

Therefore, the integration of the ICM practices along with the CA-background needs to be developed in a holistic manner so as to achieve the long-term sustainability and profitability of the $\mathrm{M}_{\mathrm{WR}}$. With this hypothesis, we have evaluated the different ICM modules for five years in a $M_{W R}$ of the north-western India, chiefly aimed to improve the crop and water productivity, economic profitability, sustainability and soil biological properties.

\section{Results}

\section{Five years' trends and pooled maize grain and stover yields}

During the initial year, the maize grain yield did not differ significantly among the ICM modules, although the highest yield was recorded under the $\mathrm{ICM}_{8}$. Nevertheless, from the second year onwards, the different ICM modules had the significant $(p<0.05)$ impacts on the maize grain yield (Fig. 2a). The ICM 7 consistently produced the highest yield across the years, which was closely followed by the ICM 8 . Similarly, the highest stover yield across the years was recorded with $\mathrm{ICM}_{7}$, except first year (Fig. 2b). The highest pooled grain (5.2 Mg ha ${ }^{-1}$ ) and stover $\left(8.7 \mathrm{Mg} \mathrm{ha}^{-1}\right.$ ) yields were recorded with the $\mathrm{ICM}_{7}$, being close to the $\mathrm{ICM}_{3-6 \& 8}$. On an average, the ICM $\mathrm{I \& 8}_{7}$ had produced $5.9-21 \%$ and 5.8-18.4\% greater grain and stover yields, respectively, over the $\mathrm{ICM}_{1-6}$ (Table 2).

\section{Five years' trends and pooled wheat grain and straw yields}

The different ICM modules did not impact the wheat grain yield significantly during the first three years. While, at the fourth year, the ICM 5 had the highest yield, being significantly higher than the $\mathrm{ICM}_{1-3}$, and subsequently in the fifth year, it was ICM 8 which outperformed significantly $(p<0.05)$ over the $\mathrm{ICM}_{4}$ (Fig. $2 \mathrm{c}$ ). Similarly, the straw yield did not differ significantly among the ICM modules in the initial three years, but significantly a greater yield was registered with the $\mathrm{ICM}_{8}$ in the fourth and fifth years (Fig. 2d). However, the mean grain and straw yields under the $\mathrm{ICM}_{5-8}(\mathrm{CA}$-based ZT) was 8.4-11.5\% and 7-14\% greater than the CT-based residue removed (ICM $1-4)$ modules (Table 2).

\section{System yields in terms of maize grain equivalents}

The ICM modules had a significant impact on the maize grain equivalents $\left(\mathrm{M}_{\mathrm{GEY}}\right)$ across the years, except during the initial two years (201516 and 2016-17), wherein the $\mathrm{ICM}_{7}$ produced the highest yield during the 2017-18 and 2019-20, which was significantly greater than the $\mathrm{ICM}_{1-4}$ to the tune of $19-22 \%$ and $17-26 \%$, respectively. While, in 2018-2019, the highest yield was recorded with the ICM, which was 
significantly higher than the $\mathrm{ICM}_{1-4}$ by $16-22 \%$. Averaged across the five years, the $\mathrm{ICM}_{5-8}$ had $6-15 \%$ system $\mathrm{M}_{\mathrm{GEY}}$ advantage over the ICM ${ }_{4}$ (Table 3).

\section{System water use and productivity}

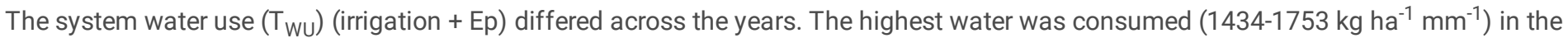
$\mathrm{ICM}_{182}$, while it was relatively lesser under the $\mathrm{ICM}_{3-8}\left(1324-1663 \mathrm{~kg} \mathrm{ha}^{-1} \mathrm{~mm}^{-1}\right)$. On an average, the ICM $3-8$ saved $6.5 \%$ system water use compared to the $\mathrm{ICM}_{1 \& 2}$ (Fig. 3a). In contrast, the highest water productivity $\left(\mathrm{W}_{\mathrm{P}}\right)$ was observed with the ICM $\mathrm{ICM}_{3}(2015-16)$, ICM 7 (2016-17, 2017-18), and $\mathrm{ICM}_{8}$ (2018-19). While, in 2019-20, the ICM $\mathrm{I}_{78}$ produced the similar $\mathrm{W}_{\mathrm{P}}$, but significantly higher than the ICM $1-4$. The average $\mathrm{W}_{\mathrm{P}}$ under CA-based residue retained modules $\left(\mathrm{ICM}_{5-8}\right)$ was 7.7-19.6\% greater than the $\mathrm{CT}\left(\mathrm{ICM}_{1-4}\right)$ practices (Fig. 3b).

\section{System variable production costs and economic returns}

Across the years, the variable input costs differed among the ICM modules. The highest system input cost was incurred with the ICM

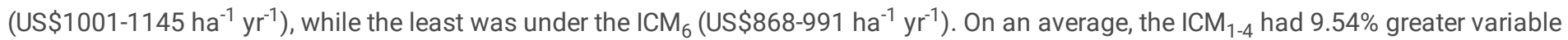
production costs compared to the $\mathrm{ICM}_{5-8}$ (Fig. 4a). Furthermore, the ICM $\mathrm{I}_{78}$ gave the highest net economic returns, resulting chiefly due to greater yields and lesser production costs incurred. The average increment in the net returns under the ICM I $_{78}$ was $23.6-29.5 \%$ compared to the $\mathrm{ICM}_{1-4}$ (Fig. 4b).

\section{Soil properties}

The ICM modules had a significant impact on the variable soil properties i.e., soil organic carbon ( $\left.\mathrm{S}_{\text {oc }}\right)$, microbial biomass carbon ( $\left.\mathrm{S}_{\mathrm{MBC}}\right)$, dehydrogenase activity $\left(\mathrm{S}_{\mathrm{DH}}\right)$, alkaline phosphatase $\left(\mathrm{S}_{\mathrm{AP}}\right)$ and soil urease $\left(\mathrm{U}_{\mathrm{RE}}\right)$ activities (Fig. 5, Table 4).

\section{Soil organic carbon $\left(\mathrm{S}_{\mathrm{oc}}\right)$}

In the top 0.00-0.05 $\mathrm{m}$ soil depth, the highest $\mathrm{S}_{\mathrm{oc}}$ was recorded with the $\mathrm{ICM}_{7}$, which was significantly higher than the ICM $2 \& 4$. The increment in $\mathrm{S}_{\mathrm{oc}}$ under the $\mathrm{ICM}_{7 \& 8}$ over the $\mathrm{ICM}_{1-4}$ was to the tune of $10.2-16.2 \%$. Further, in the $0.05-0.15 \mathrm{~m}$ soil depth, the highest $\mathrm{S}_{\text {oc }}$ was recorded with the $\mathrm{ICM}_{6}$, wherein it was significantly more than the ICM , but statistically $(\mathrm{p}<0.05)$ similar to the ICM $1,2,4,5,7 \& 8$. While, there were no significant differences among the ICM modules, with respect to the $\mathrm{S}_{\mathrm{oc}}$, in the $0.15-0.30 \mathrm{~m}$ soil depth (Fig. $5 \mathrm{a}$ ).

\section{Soil microbial biomass carbon $\left(\mathrm{S}_{\mathrm{MBC}}\right)$}

The highest $\mathrm{S}_{\mathrm{MBC}}$ in the $0.00-0.05 \mathrm{~m}$ soil depth was observed under the $\mathrm{ICM}_{8}$, wherein it was similar to the ICM $\mathrm{I}_{56}$, but significantly higher than the $\mathrm{ICM}_{1-4 \& 7}$. The $\mathrm{ICM}_{8}$ had 6-23\% greater $\mathrm{S}_{\mathrm{MBC}}$ than the $\mathrm{ICM}_{1-4}$. While, in the 0.05-0.15 $\mathrm{m}$ soil depth, the highest $\mathrm{S}_{\mathrm{MBC}}$ was recorded in the ICM $\mathrm{ICM}_{6}$, being significantly greater than the $\mathrm{ICM}_{1-5}$ to the tune of $12-22.8 \%$, but similar to the ICM $7 \& 8$. In contrast, at lower soil depth (0.15$0.30 \mathrm{~m}$ ), the highest $\mathrm{S}_{\mathrm{MBC}}$ was observed under the $\mathrm{ICM}_{3}$, and being greater than that of the ICM $1,2 \& 4-8$ (Fig. 5b).

\section{Soil dehydrogenase activity $\left(\mathrm{S}_{\mathrm{DH}}\right)$}

The $\mathrm{ICM}_{6}$ had the highest $\mathrm{S}_{\mathrm{DH}}$ which was similar with the $\mathrm{ICM}_{7 \& 8}$, but significantly greater than the ICM $1-5$ to the tune of $7.8-21 \%$ in the top 0.00-0.05 m soil depth. Further, in the second depth $(0.05-0.15 \mathrm{~m})$, the $\mathrm{ICM}_{8}$ recorded the highest $\mathrm{S}_{\mathrm{DH}}$, wherein it was similar to the $\mathrm{ICM}_{6 \& 7}$, but shown $17-36.6 \%$ greater $\mathrm{S}_{\mathrm{DH}}$ than the $\mathrm{ICM}_{1-5}$. In the $0.15-0.30 \mathrm{~m}$ soil depth, $\mathrm{ICM}_{5}$ resulted in the highest $\mathrm{S}_{\mathrm{DH}}$. Averaged across the soil depths, the $\mathrm{ICM}_{6-8}$ gave $4-21 \%$ higher $\mathrm{S}_{\mathrm{DH}}$ than the $\mathrm{ICM}_{1-5}$ (Table 4).

\section{Soil alkaline phosphatase $\left(\mathrm{S}_{\mathrm{AP}}\right)$}

The highest $\mathrm{S}_{\mathrm{AP}}$ in the top $0.00-0.05 \mathrm{~m}$ soil depth was recorded with the $\mathrm{ICM}_{8}$, being significantly higher than the ICM $1-5$, but similar to the $\mathrm{ICM}_{6 \& 7}$. Indeed, the $\mathrm{ICM}_{7 \& 8}$ resulted in 8.3-32.3\% higher $\mathrm{S}_{\mathrm{AP}}$ compared to the $\mathrm{ICM}_{1-5}$. While, in the $0.05-0.15 \mathrm{~m}$ soil depth, the highest $\mathrm{S}_{\mathrm{AP}}$ was observed with the $\mathrm{ICM}_{6}$, where it was significantly more than the ICM $1-4 \&$, but at par with the ICM $5 \& 7$. Further, at $0.15-0.30$ m, no significant difference in $\mathrm{S}_{\mathrm{AP}}$ was noticed among the ICM modules (Table 4).

\section{Soil urease $\left(\mathrm{U}_{\mathrm{RE}}\right)$}


The $U_{R E}$ in the $0.00-0.05 \mathrm{~m}$ soil depth was the highest with the $\mathrm{ICM}_{8}$, in which it was similar to the ICM $4-7$, but significantly greater than the $I_{1 C M}$. The increment in $U_{R E}$ under ICM $I_{7 \& 8}$ over the $I_{1 C M}$ (CT modules) was to the tune of 12.7-27.2\%. Similarly, in the $0.05-0.15$ m, the highest $\mathrm{U}_{\mathrm{RE}}$ was recorded with the ICM $\mathrm{ICM}_{8}$, which was significantly greater than the ICM $\mathrm{I}_{1-4}$, but similar to the ICM $\mathrm{ICM}_{5-7}$. As expected, the ICM produced 8-27\% higher $\mathrm{U}_{\mathrm{RE}}$ compared to the $\mathrm{ICM}_{1-4}$. However, in the lowest soil layer $(0.15-0.30 \mathrm{~m})$, no significant differences in $\mathrm{U}_{\mathrm{RE}}$ were observed among the ICM modules (Table 4).

\section{Sustainable yield index $\left(\mathrm{S}_{\mathrm{Yl}}\right)$}

Among the ICM modules in the maize, the $\mathrm{ICM}_{7}$ had the greater $\mathrm{S}_{\mathrm{Y} \mid}$, but being at par to the ICM $1,5,6 \& 8$, which was $12-15.2 \%$ greater than the $I_{2-4}$. Again, $S_{Y I}$ in wheat was the highest under the $\mathrm{ICM}_{7}$, similar with $\mathrm{ICM}_{5 \& 8}$, being 17.9-25.3\% greater than the CT-based ICM 1 -4 $\mathrm{modules}$ In the case of $M_{W R}$, the $S_{Y I}$ was the highest under the $I_{7 C M}$, which was $13.4-18.6 \%$ higher than the ICM $1-4$, and similar to ICM $(F i g$. 6 ).

\section{Discussion}

The rice-wheat is the commanding rotation in northern India's ecologies. However, of late, from the resource exploitation to their judicious use for sustained yield, save water and improve soil-based properties is the focus ${ }^{26,19}$, besides achieving SDGs ${ }^{12}$. Seeing the degradation of natural resources, stagnation in crop yields and other constraints in adoption of rice-wheat rotation ( $\left.R_{W R}\right)$, it is thus noteworthy to identify the alternative crops and cropping rotations to sustain the food security. Maize $\nabla$ Queen of cereals $\nabla$ being a $\mathrm{C}_{4}$ plant, has wider adaptability under the diverse climate, thus could be a striking substitute of rice ${ }^{2}$. Every year, in the rice-wheat belt of north western India, the ground water falls off by $0.30-0.40 \mathrm{~m}^{27}$, and therefore, acreage under maize is likely to increase with the time. It is clearly evident that rice is the main water consumer ${ }^{28}$, maize could be a potential choice for accompanying wheat in this area, as it saves irrigation water, fulfils demand for palatable fodder and industries. Rice residue burning rather than returning to the soil, is another concern which not only deteriorates the air quality, but also have acute effects on human health ${ }^{8}$. Thus, the $\mathrm{M}_{\mathrm{WR}}$ has a potential to replace the water guzzling rice under the $\mathrm{R}_{\mathrm{WR}}$. The CA-based ICM practices in $\mathrm{M}_{\mathrm{WR}}$ would intend for sustainable residue recycling, improve soil properties ${ }^{29,19}$ and sustain long-term production $^{30}$.

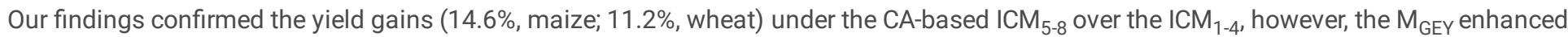
by $12.3 \%$ (5 years' av.). The $\mathrm{ICM}_{5-8}$, proved superior because of $\mathrm{ZT}$, crops residue, and eventually the efficient use of inputs ${ }^{31,32}$ along with $\mathrm{L}_{\mathrm{BFS}}$ consortia and $\mathrm{A}_{\mathrm{MF}}$. Most soil organic matter $\left(\mathrm{S}_{\mathrm{OM}}\right)$ originates from the residues, and crops produce is positively linked with $\mathrm{S}_{\mathrm{OM}}{ }^{33}$; crops residue retention helps $S_{O M}$ build up, soil temperature moderation, improved water holding capacity, microbial and enzymatic activities, and nutrients mobilization in the rhizospheric zone ${ }^{34,35}$. In cereals, $A_{M F}$ has extraordinary importance in boosting the yields ${ }^{36}$, and has capacity to acquire immobile nutrients beyond the radius of roots through their hyphal network ${ }^{37,38}$ owing to greater nutrients / water taken up ${ }^{39,40}$, ultimately improve yields ${ }^{41,42}$.

$\mathrm{ICM}_{5-8}$ increased $0.49 \mathrm{Mg} \mathrm{ha}^{-1}$ pooled wheat yield, but was $0.73 \mathrm{Mg} \mathrm{ha}^{-1}$ in maize, whereas, the yield advantage was more $\left(0.96 \mathrm{Mg}^{-1}\right)$ with ZT bed planted maize $\left(\mathrm{ICM}_{7-8}\right)$ than to the $\mathrm{ICM}_{1-4}$ (Table 2, Fig. 2). Excess (heavy rains) and deficit (longer dry spells) moisture are the common obstacles in the rainy season maize ecologies, but such variability does not exist during winters (wheat season). Residue retention in the $\mathrm{ICM}_{5-8}$ infiltrate more water (Fig. 1d), and creates better aeration for the maize crop, bed planted maize (ICM $7 \& 8$ ) combining residues recorded yield advantage. Some meta-analysis studies have shown that the $A_{M F}$ helps to tolerate such stresses ${ }^{43,44}$. The $L_{B F s}$ fixes atmospheric- $\mathrm{N}$ and helps in solubilizing the insoluble $\mathrm{P}$ compounds which facilitate nutrient uptake, and improves the soil fertility, thereby, reduces the rate of chemical fertilizers up to $25 \%$.

Water productivity $\left(\mathrm{W}_{\mathrm{P}}\right)$ is the crop yield unit ${ }^{-1}$ of water consumption. Five years' results delineated that the $\mathrm{ICM}_{5-8} \mathrm{could}$ save $\sim 7 \%$ irrigation water, compared to the $\mathrm{ICM}_{1 \& 2}$ (Fig. 3a). Long-time ZT tilled conditions where residues are retained, not only conserve the soil water, but facilitate better moisture regimes in the effective rhizosphere, and resulted in greater $W_{P}{ }^{32,45}$. In the ICM I-8 modules, the surface residues could reduce the losses of water vapour and retained moisture for the longer period, thus requiring lesser irrigations. Further, the bed planting coupled with the crops residues has twin benefits of greater infiltration and lower water application rates ${ }^{46,47,4}$. In 2017-18 and 2018-19, the higher $W_{P}$ was associated with the least water input coupled with greater yields than in other years (Fig. 3b).

Modules $\mathrm{ICM}_{5-6}$ being lesser expensive, on account of lesser tillage operations involved and thus saved labor costs in various physical field operations, whereas, the $\mathrm{ICM}_{7-8}$ were relatively costlier as these involved extra expenses in reshaping the beds (Fig. $4 \mathrm{a}$ ). While, the $\mathrm{ICM}_{1 \& 4}$ incurred the highest cost owing to more trafficking in different tillage operations ${ }^{48}$. The sequential tillage included the extra fuel cost, 
eventually these modules gave lower yield, as indicated in the inclination of economic net returns ${ }^{5}$. Of course, the timely sowing of the succeeding wheat under the ZT conditions gave yield advantage $\mathrm{Z}^{49,50}$ with the improved economic returns ${ }^{48}$. These results also reinforce the earlier research work in the adjoining ecologies $32,51,49$.

The ICM based agronomic management have vital role in the soil profile activities, and sustaining the soil health in the long-run ${ }^{52}$. Continuous crop residues recycling significantly improves the $\mathrm{S}_{\mathrm{OC}}$ fractions ${ }^{53}$ and total $\mathrm{S}_{\mathrm{OC}}{ }^{45}$. These CA-based practices have been widely analyzed for improving the $\mathrm{S}_{\mathrm{OC}}$ and the microbial population size ${ }^{54}$. Interestingly, over the years, the $\mathrm{ZT}+$ residues could increase the $\mathrm{S}_{\mathrm{OC}}$, particularly by releasing the considerable rhizo-depositions through hidden half and lower decaying rates ${ }^{40}$. Our results showed that the $\mathrm{S}_{\mathrm{OC}}$ changed remarkably in the top soil layers, and $\mathrm{ICM}_{5-8}$ increased the $\mathrm{S}_{\mathrm{OC}}$ storage by $12.1 \%$ in the top soil layer over the CT-based ICM $1-4$ (Fig. $5 a)$, as intensive tillage operations facilitate the loss of $S_{O C}$, which is undesirable for the global $\mathrm{C}$ balance 55,45 .

The $\mathrm{S}_{\mathrm{MBC}}$ is the living component (i.e., bacteria and fungi) of $\mathrm{S}_{\mathrm{OM}}$, being the key indicator for $\mathrm{S}_{\mathrm{OC}}$. In spite of small size, being a labile pool of $\mathrm{S}_{\mathrm{OM}}{ }^{56}$, it contributes to the transformation or cycling of $\mathrm{S}_{\mathrm{OM}}{ }^{57,58}$. In this study, the CA-based residue retained modules had $13.7 \%$ greater $\mathrm{S}_{\mathrm{MBC}}$ in the 0.0-0.15 soil layers than the modules where residues were removed (Fig. $5 \mathrm{~b}$ ), as regular residue addition accumulated the soil $\mathrm{C}$ that enhanced the $S_{M B C}$ and other microbial activities ${ }^{46,59}$. Moreover, the ZT conditions with sufficient crops residue are more conducive for the fungal hyphae growth, with additional supply of $A_{M F}$ along with $L_{B F s}$ further enhanced the fungal population and diversity, which could play an important role in the $\mathrm{C} / \mathrm{N}$ cycling through their hyphal networks ${ }^{60}$. The $\mathrm{S}_{\mathrm{DH}}$ is the most intuitive bioindicators, describing the soil fertility ${ }^{61}$. It is associated with the $S_{O M}$ oxidation, and its activity depends on the microorganisms' abundance and activity ${ }^{62}$. Current results showed a $10.1 \%$ improvement in the $\mathrm{S}_{\mathrm{DH}}$ activity under the CA-based $\mathrm{ICM}_{5-8}$ modules, over CT-based practices (Table 4). The $\mathrm{S}_{\mathrm{MBC}}$ and $\mathrm{S}_{\mathrm{DH}}$ activities are directly associated with the recycling of the organic amendments, such as, the crops residues ${ }^{63,46}$.

Phosphatase activity is needed for P-mineralization and release of the $\mathrm{PO}_{4}{ }^{3-}$ for the plant uptake. Often it is stated that the phosphatase activities (alkaline / acid) are greater in the $\mathrm{P}$ deficient soils ${ }^{65}$, and the current study soils are alkaline in nature ( $\left.\mathrm{pH} 7.9\right)$ with only $13 \mathrm{~kg}$ ha ${ }^{-1}$ available P. The P deficiency, residue addition and stoichiometric changes ${ }^{66}$ would exhilarate the phosphatase activity under the CA-based modules. The urease activity responsible for the $\mathrm{N}$ mineralization and $\mathrm{NH}_{3}$ release through hydrolysing the $\mathrm{C}-\mathrm{N}$ bond of the amides ${ }^{67}$. The residue based ICMs recorded greater urease, as residues acts as a substrate for the urease, and eventually help in increasing the $\mathrm{N}$ availability for plant uptake. The $\mathrm{S}_{\mathrm{OC}}, \mathrm{S}_{\mathrm{MBC}}, \mathrm{S}_{\mathrm{DH}}, \mathrm{A}_{\mathrm{PA}}$ and $\mathrm{U}_{\mathrm{RE}}$ activities are directly linked with and the soil biological properties, and hence the soil fertility. We conclude that the CA-based residue retained modules of $\mathrm{M}_{\mathrm{WR}}$ improved crops yields, farm economic profitability, and conserved the soil moisture. Such practices could also supplement the nutrients, sustain the crop yields, conserve natural resources, especially water and boost up the soil microbial functions for the long-term sustainability.

\section{Conclusions}

The five years' results clearly indicated the superiority of the CA-based residue retained ICM $_{5-8}$ modules, which produced $9.5-14.3 \%$ greater system maize grain equivalents $\left(\mathrm{M}_{\mathrm{GEY}}\right)$ over the $\mathrm{CT}$-based modules $\left(\mathrm{ICM}_{1-4}\right)$. Further, the $\mathrm{ICM}_{2-8}$ saved 6.5-8.0\% irrigation water, and ICM 5 -8 recorded 10.3-17.8\% higher system $W_{P}$ than the residue removed $\left(\mathrm{ICM}_{1-4}\right)$ modules. Of course, the conventional modules (ICM $\left.1-4\right)$ were expensive, however, $\mathrm{ICM}_{5-8}$ gave 24.3-27.4\% extra returns than the $\mathrm{ICM}_{1-4}$, eventually made them economically more profitable. The residue retained modules $\left(\mathrm{ICM}_{5-8}\right)$ registered 7.1-14.3\% (0.0-0.15 $\left.\mathrm{m}\right)$ greater $\mathrm{S}_{\mathrm{OC}}$ than the $\mathrm{ICM}_{1-4}$, indicating the positive impacts of the residue addition which would be useful in sustaining the soil health in long-run. On an average, in 0.0-0.15 m depths, the soil biological activities i.e.,

$S_{M B C}(10.1-16.7 \%), S_{D H}(10-15.6 \%), S_{A P}(14.8-18.1 \%)$, and $U_{R E}(16.5-20 \%)$ increased in the ICM $I_{5-8}$ compared to the ICM ${ }_{1-4}$, thus the effect of residue retention was more pronounced in the upper soil layers than in lower depths. Therefore, the ZT residue retained modules either $\mathrm{ICM}_{7 \& 8}$ or ICM $\mathrm{I}_{86}$ could be acceptable for their adoption in the $\mathrm{M}_{\mathrm{WR}}$ for improving the yields, economic profitability and soil biological properties in the north western India and probably in other similar agro-ecologies.

\section{Materials And Methods}

\section{Experimental site, location and climate}

Five years' field experimentation on ICM was started in 2014-15 at the ICAR-Indian Agricultural Research Institute $\left(28^{\circ} 35^{\prime} \mathrm{N}\right.$ latitude, $77^{\circ} 12^{\prime} \mathrm{E}$ longitude, $229 \mathrm{~m} \mathrm{MSL}$ ), New Delhi, India. The study site comes under the 'Trans $\mathrm{I}_{\mathrm{GPs}}$ ', being semi-arid with an average annual rainfall of 650 $\mathrm{mm}$, of which $\sim 80 \%$ occurs in July-September (south-west monsoon). The mean max. / min. air temperature ranges between $20-40^{\circ} \mathrm{C}$ and $4-$ $28^{\circ} \mathrm{C}$, respectively. The five years (2014-2019) weather data were recorded from the observatory adjoining to the experimental field, and 
presented in supplementary table 1. Before start of the experiment, a rainy season Sesbania was grown in 2014 to ensure the uniform fertility across the blocks. Initial soil samples (0.0-0.15 m depth) were collected in October 2014 after incorporating the Sesbania residues in soil. The soil samples were processed for the chemical analysis. The study site had a pH of $7.9(1: 2.5 \text { soil and water ratio })^{68}, 3.8 \mathrm{~g} \mathrm{~kg}{ }^{-1}$ soil $^{2}$ organic- ${ }^{69}, 94.1 \mathrm{~kg} \mathrm{ha}^{-1} \mathrm{KMnO}_{4}$ oxidizable $\mathrm{N}^{70}, 97 \mu \mathrm{g} \mathrm{g}^{-1}$ soil microbial biomass carbon ${ }^{71}, 51.3 \mu \mathrm{g} \mathrm{PNP} \mathrm{g}^{-1}$ soil h$^{-1}$ alkaline phosphatase ${ }^{72}$, $53.0 \mu \mathrm{g} \mathrm{TPF} \mathrm{g}{ }^{-1}$ soil $\mathrm{d}^{-1}$ dehydrogenase ${ }^{73}$, and $13.5 \mu \mathrm{g} \mathrm{NH}_{4}-\mathrm{N} \mathrm{g}^{-1}$ soil h$^{-1}$ urease $^{74}$.

\section{Description of different ICM modules}

The eight ICM modules were tested, comprising of four conventional tillage (CT)-based (ICM $1-4)$ and four conservation agriculture (CA)based $\left(\mathrm{ICM}_{5-8}\right)$ modules, replicated thrice in a complete randomized block design with the plot size of $60 \mathrm{~m}^{2}(15 \mathrm{~m} \times 4.5 \mathrm{~m})($ Table. 1$)$. The crop residues were completely removed in the CT-based modules $\left(\mathrm{ICM}_{1-4}\right)$, while in the $\mathrm{ICM}_{5-8}$ modules, in-situ wheat $\left(\sim 3 \mathrm{Mg}^{-1}\right.$ on dry weight basis) ) and maize ( $5 \mathrm{Mg} \mathrm{ha}^{-1}$, on dry weight basis) residues were retained on the soil surface during all the seasons of crops cultivation (Footnote table 1, Fig. 1a,b).

In the $\mathrm{ICM}_{1-4}$ modules, the field preparation was carried out by sequential tillage operations, such as, deep ploughing using the disc harrow, cultivator/rotavator twice $(0.15-0.20 \mathrm{~m})$, followed by levelling in each season. In the ICM $3-4$, the raised beds of $0.70 \mathrm{~m}$ bed width (bed top $0.40 \mathrm{~m}$ and furrow $0.30 \mathrm{~m}$ ) were formed during each cropping cycle using the tractor mounted bed planter, and simultaneously wheat sowing was done (Fig. $1 \mathrm{c})$. In the case of maize, ridges ( 0.67 m length) were prepared using the ridge maker. In the $\mathrm{CA}^{-b a s e d} \mathrm{ICM}_{5-8}$ modules, the tillage operations, such as, seed and fertilizer placement were restricted to the crop row-zone in maize and wheat both. In the $\mathrm{ICM}_{7 \& 8}$, the permanent raised beds ( $0.67 \mathrm{~m}$ mid-furrow to mid-furrow, $0.37 \mathrm{~m}$ wide flat tops, and $0.15 \mathrm{~m}$ furrow depth), were prepared (Fig. $1 \mathrm{~d})$. However, these beds were reshaped using the disc coulter at the end of each cropping cycle without disturbing the surface residues. The sowing was accomplished using the raised bed multi-crop planter.

\section{Cultural operations and the fertilizer application}

During every season, the maize (cv. PMH 1) was sown in the first week of July using $20 \mathrm{~kg} \mathrm{seed} \mathrm{ha}^{-1}$. The wheat (cv. HD 2967) crop was sown in the first fortnight of November using the seed-cum fertilizer drill $\left(\mathrm{ICM}_{1-2}\right)$, bed planter $\left(\mathrm{ICM}_{3-4}\right)$ and zero-till seed drill (ICM 5 -8 $)$ at 100 $\mathrm{kg}$ seed ha ${ }^{-1}$. The chemical fertilizers ( $N, P$ and $K$ ) were applied as per the modules described in the footnote of Table 1. At sowing, the full doses of phosphorous $(\mathrm{P})$ and potassium (K) were applied using the di-ammonium phosphate (DAP) and muriate of potash (MOP), and the nitrogen $(\mathrm{N})$ supplied through DAP. The remaining $\mathrm{N}$ was top-dressed through urea in two equal splits after the first irrigation and tasseling / silking stages in maize, and crown root initiation and tillering stages of wheat. In the modules receiving $3 / 4$ fertilizers (ICM $2,4,6,8)$, the seeds were treated with the NPK liquid bio-fertilizer $\left(\mathrm{L}_{\mathrm{BFs}}\right)$ (diluted $250 \mathrm{ml}$ formulation 2.5 liters of water ha $\left.{ }^{-1}\right)$, and an arbuscular mycorrhiza $\left(\mathrm{A}_{\mathrm{MF}}\right)$ was broadcasted at $12 \mathrm{~kg} \mathrm{ha}^{-1}$ as has been described by ${ }^{75}$. This $\mathrm{L}_{\mathrm{BFs}}$ had the microbial consortia of $\mathrm{N}$-fixer (Azotobacter chroococcum), $\mathrm{P}$ (Pseudomonas) and K (Bacillus decolorationis) solubilizers, procured from the commercial biofertilizer production unit of the Microbiology Division, ICAR-Indian Agricultural Research Institute, New Delhi (Patentee: ICAR, Govt. of India). Weeds were managed by integrating the preand post-emergence herbicides, and their combinations along with the hand weeding-mulching, as mentioned in the concerned modules (Footnote table 1). However, in the CA-based modules $\left(\mathrm{ICM}_{5-8}\right)$, the non-selective herbicide glyphosate $\left(1 \mathrm{~kg}^{-1}\right)$ was used 10 days before the sowing. The need-based integrated insect-pests and disease management practices were followed uniformly across the modules.

\section{Soil sampling and analysis}

Before start of the experiment, the soil sampling was done from 0.0-0.15 $\mathrm{m}$ depth. Afterwards, five random samples from each module from $0.0-0.30 \mathrm{~m}$ soil depth were collected at the flowering stage of $5^{\text {th }}$ season wheat. These samples were taken from the three soil depths $(0.0$ to $0.05,0.05-0.15$ and $0.150-0.30 \mathrm{~m}$ ) using the core sampler. The ground, air-dried soil samples, passed through a $0.2 \mathrm{~mm}$ sieve were used for the determination of the Walkley and Black organic carbon $\left(\mathrm{S}_{\mathrm{OC}}\right)$, as described by ${ }^{76}$. For the soil biological properties, the soil samples were processed, and stored at $5^{\circ} \mathrm{C}$ for $18-24 \mathrm{~h}$, then analyzed the soil microbial biomass carbon $\left(\mathrm{S}_{\mathrm{MBC}}\right)$, dehydrogenase $\left(\mathrm{S}_{\mathrm{DH}}\right)$, alkaline phosphate $\left(\mathrm{S}_{\mathrm{AP}}\right)$ and the urease $\left(\mathrm{U}_{\mathrm{RE}}\right)$ activities.

\section{The soil microbial biomass carbon $\left(\mathrm{S}_{\mathrm{MBC}}\right)$}

The $\mathrm{S}_{\mathrm{MBC}}$ was measured using the fumigation extraction method as proposed by ${ }^{71}$. The pre-weighed samples from the respective soil depths were fumigated with the ethanol-free chloroform for the $24 \mathrm{~h}$. Separately, a non-fumigated set was also maintained. Further, $0.5 \mathrm{M}$ $\mathrm{K}_{2} \mathrm{SO}_{4}$ (soil: extractant 1:4) was added, and kept on a reciprocal shaker for $30 \mathrm{~min}$. and then filtered through a Whatman No. 42 filter paper. 
$\mathrm{OC}$ of the filtrate was measured through the dichromate digestion, followed by the back titration with $0.05 \mathrm{~N}$ ferrous ammonium sulphate.

The $\mathrm{S}_{\mathrm{MBC}}$ was then calculated using the equation: $\mathrm{S}_{\mathrm{MBC}}=\mathrm{EC} \times 2.64$

Where, $E C=\left(C_{\text {org }}\right.$ in fumigated soil $-C_{\text {org }}$ in non-fumigated soil $)$, and expressed in $\mu g \mathrm{Cg}^{-1}$ soil.

\section{The dehydrogenase activity $\left(\mathrm{S}_{\mathrm{DH}}\right)$}

The $\mathrm{S}_{\mathrm{DH}}$ activity (mg TPF $\mathrm{g}^{-1}$ soil $\left.\mathrm{d}^{-1}\right)$ was assessed using the method of ${ }^{73}$. The soil sample $(\sim 6 \mathrm{~g})$ was saturated with $1.0 \mathrm{ml}$ freshly prepared $3 \%$ triphenyltetrazolium chloride (TTC), and then incubated for $24 \mathrm{~h}$ under the dark. Later on, the methanol was added to stop the enzyme activity, and the absorbance of the filtered aliquot was read at $485 \mathrm{~nm}$.

\section{The alkaline phosphatase activity $\left(\mathrm{S}_{\mathrm{AP}}\right)$}

The $A_{P A}$ activity was estimated in $1.0 \mathrm{~g}$ soil saturated with $4 \mathrm{ml}$ of the modified universal buffer (MUB) along with $1 \mathrm{ml}$ of p-nitrophenol phosphate followed by incubation at $37^{\circ} \mathrm{C}$ for $1 \mathrm{~h}$. After incubation, $1 \mathrm{ml}$ of $0.5 \mathrm{M} \mathrm{CaCl}_{2}$ and $4 \mathrm{~mL}$ of $\mathrm{NaOH}$ were added and the contents filtered through Whatman No. 1 filter paper. The amount of p-nitrophenol in the sample was determined at $400 \mathrm{~nm}^{72}$ and the enzyme activity was expressed as $\mu \mathrm{g} \mathrm{p}-\mathrm{NP} \mathrm{g}^{-1}$ soil $^{-1}$.

\section{The urease activity}

Urease activity was measured using $10 \mathrm{~g}$ soil suspended in $2.5 \mathrm{ml}$ of urea solution ( $0.5 \%$ ). After incubating for a day at $37^{\circ} \mathrm{C}, 50 \mathrm{ml}$ of $1 \mathrm{M}$ $\mathrm{KCl}$ solution was added. This was kept on a shaker for 30 minutes and the aliquot was filtered through Whatman No. 1 filter paper. To the filtrate $(10 \mathrm{ml}), 5 \mathrm{ml}$ of sodium salicylate and $2 \mathrm{ml}$ of $0.1 \%$ sodium dichloro-isocyanide solution were added and the green color developed was measured at $690 \mathrm{~nm}^{74}$. These values are reported as $\mu \mathrm{g} \mathrm{NH}_{4}-\mathrm{N} \mathrm{g}^{-1}$ soil h${ }^{-1}$.

\section{Water application and productivity}

In experimental modules, water was given through the controlled border irrigation method. The current meter was fixed in the main lined rectangular channel, and the water velocity was measured. To get the flow discharge, then multiplied with area of cross section of the channel. The following formulae were used to calculate the applied irrigation water quantity and depth³.

Irrigation water applied $(L)=F \times t$. (i)

Depth $(\mathrm{mm})=L \div A / 1000$. (ii)

Where, $F$ is flow rate $\left(\mathrm{m}^{3} \mathrm{~s}^{-1}\right)$, $t$ is time $(s)$ taken in each irrigation in each module and $A$ is area $\left(\mathrm{m}^{2}\right)$

The effective precipitation ( $E_{p}$, difference between total rainfall and the actual evapotranspiration) was calculated, and then $E_{p}$ was added to the irrigation water applied to calculate the total water applied in each module. Across the maize and wheat modules (ICM ${ }_{1-8}$ ), irrigations were given at the critical growth stages, such as, knee high and silking / tasseling (maize) and crown root formation, maximum tillering, flowering, heading / milking (wheat) stages, and after long dry spell ( $\geq 10$ - days).

On the basis of the soil water depletion pattern (at the depth of $0.60 \mathrm{~m}$ ), in each season, 3-6 irrigations were given to maize, while wheat received 5-8 irrigations per season or crop including the pre-sowing irrigation. The rainfall data were obtained from the meteorological observatory located in the adjoining field. The water productivity ( $\mathrm{kg}$ grains ha $\mathrm{mm}^{-1}$ of water) was measured as per the equation given below:

Water productivity = economic yield $\left(\mathrm{kg} \mathrm{ha}^{-1}\right) /$ total water applied $(\mathrm{mm})$ (iii)

Additionally, the systems water productivity $\left(S_{W P}\right)$ was also estimated by adding the water productivity $\left(W_{P}\right)$ of both maize and wheat crops grown under the $\mathrm{M}_{\mathrm{WR}}$.

\section{Yield measurements}

In each season, the maize and wheat crops were harvested during the months of October and April, respectively, leaving $0.75 \mathrm{~m}$ border rows from all the corners of each module. The crops were harvested from the net sampling area $\left(6 \mathrm{~m} \times 3 \mathrm{~m}, 18 \mathrm{~m}^{2}\right)$ located at the center of each plot. Maize crop was harvested manually and the wheat by using the plot combine harvester. All the harvested produce was sun dried before 
threshing and the grain and straw / stover yields were weighed separately. The stover/straw yields were measured by subtracting the grain weight from the total biomass. To compare the total (system) productivity of the different ICM modules, the system yield was computed, taking maize as the base crop, i.e., the maize equivalent yield $\left(\mathrm{M}_{\mathrm{GEY}}\right)$ using the equation ${ }^{20}$ :

$M_{G E Y}\left(M g h a^{-1}\right)=Y m+\{(Y w \times P w) \div P m\}$

Where, $Y_{m}=$ maize grain yield $\left(M g h a^{-1}\right), Y_{w}=$ wheat grain yield $\left(M g h a^{-1}\right), P_{m}=$ price of maize grain $\left(U S S \mathrm{Mg}^{-1}\right)$ and $P_{w}=$ price of wheat grain $\left(U S S g^{-1}\right)$

\section{Farm economics}

Under different ICM modules, the variable production costs and economic returns were worked out based on the prevailing market prices for the respective years. The production costs included the cost of various inputs, such as, rental value of land, seeds, pesticides, $L_{\mathrm{BFs}} /$ consortia, $A_{M F}$, labor, and machinery; tillage / sowing operations, irrigation, mineral fertilizers, plant protection, harvesting, and threshing etc. The costs for the crops' residues were also considered. The system total returns were computed by adding the economic worth of the individual crop, however, the net returns were the differences between the total returns to the variable production costs of the respective module. The Govt. of India's minimum support prices (MSP) were considered for the conversion of grain yield to the economic returns (profits) during the respective years. Further, the system net returns $\left(\mathrm{S}_{\mathrm{NR}}\right)$ were worked out by summing the net income from both maize and the wheat in Indian rupees (INR), and then converted to the US\$, based on the exchange rates for different years.

\section{Sustainable yield index $\left(\mathrm{S}_{\mathrm{Y}}\right)$}

77,78 described the $S_{Y \mid}$ as a quantitative measure of the sustainability of agricultural rotation/practice. The sustainability could be interpreted using the standard deviation $(\sigma)$ values, where the lower values of the $\sigma$ indicate the greater sustainability and vice-versa. Total crop productivity of maize and wheat under the different ICM modules was computed based on the five years' mean yield data. $S_{\mathrm{YI}}$ was calculated using Eq. ${ }^{78}$.

$\mathrm{S}_{\mathrm{Yl}}=\left(-\overline{\mathrm{y}}_{\mathrm{a}}-\sigma_{\mathrm{n}}{ }_{1}\right) / \mathrm{Y}^{-1} \mathrm{~m}$

Where, $-\bar{y}_{a}$ is the average yield of the crops across the years under the specific management practice, $\sigma_{n-1}$ is the standard deviation and $Y^{-}$ ${ }_{m}$ is the maximum yield obtained under the set of an ICM module.

\section{Statistical analysis}

The GLM procedure of the SAS 9.4 (SAS Institute, 2003, Cary, NC) was used for the statistical analysis of all the data obtained from different ICM modules to analyze the variance (ANOVA) under the randomized block design ${ }^{79}$. Tukey's honest significant difference test was employed to compare the mean effect of the treatments at $p=0.05$.

\section{Declarations}

Authors have confirmed that all the plant studies were carried out in accordance with relevant national, international or institutional guidelines.

Acknowledgements Authors acknowledge to the ICAR-Indian Agricultural Research Institute and the Indian Council of Agricultural Research, New Delhi for providing the financial support and necessary facilities in conducting this research. We thank to Dr. O.P. Singh, Dr. M. Pal and field and lab staff for their help during the experimentation and lab studies.

\section{References}

1. Ranum, P. et al. Global maize production, utilization and consumption. Ann. N. Y. Acad Sci. 1312, 105-112 (2014).

2. Jat, S.L. et al. Energy auditing and carbon footprint under long-term conservation agriculture-based intensive maize systems with diverse inorganic nitrogen management options. Sci. Total Environ. 664, 659-668 (2019).

3. Jat, M.L. et al. Evaluation of precision land leveling and double zero-till systems in the rice-wheat rotation: Water use, productivity, profitability and soil physical properties. Soil Till. Res. 105, 112-121 (2009). 
4. Jat, M.L. et al. Double no-till and permanent raised beds in maize-wheat rotation of north-western Indo-Gangetic plains of India: effects on crop yields, water productivity, profitability and soil physical properties. Field Crops Res. 149, 291-299 (2013).

5. Biswakarma, N. et al. Five years integrated crop management in direct seeded rice-zero till wheat rotation of north-western India: Effects on soil carbon dynamics, crop yields, water productivity and economic profitability. Agric. Ecosyst. Environ. 318, 107492 (2021).

6. Ladha, J.K., Yadvinder-Singh., Erenstein, O. \& Hardy, B. Integrated crop and resource management in the rice-wheat systems of South Asia. International Rice Research Institute, Los Banos, Philippines, p. 395 (2009).

7. Pathak, H., Saharawat, Y.S., Gathala, M. \& Ladha, J.K. Impact of resource conserving technologies on productivity and greenhouse gas emission in rice-wheat system. Greenhouse Gas Sci. Tech. 1, 261-277 (2011).

8. Abdurrahman, M.I., Chaki, S. \& Saini, G. Stubble burning: effects on health and environment, regulations and management practices. Environ. Adv. 2, 100011 (2020).

9. Kedia, S., Pandey, R. \& Malhotra, A. The impact of stubble burning and poor air quality in India during the time of COVID-19, 27 July 2020. Tata Energy and Resources Institute, New Delhi (2020).

10. Keesstra, S.D. et al. The significance of soils and soil science towards realization of the United Nations Sustainable Development Goals. Soil 2, 111-128 (2016).

11. Keesstra, S. et al. Soil-related sustainable development goals: four concepts to make land degradation neutrality and restoration work. Land 7(4), 133 (2018).

12. Visser, S. et al. Soil as a basis to create enabling conditions for transitions towards sustainable land management as a key to achieve the SDGs by 2030. Sustainability 11(23), 6792 (2019).

13. Humphreys, E. et al. Halting the groundwater decline in North-West India-which crop technologies will be winners? Adv. Agron. 109, 155-217 (2010).

14. Saad, A.A. et al. Energy auditing of maize-wheat-greengram cropping system under conventional and conservation agriculture in irrigated North-western Indo-Gangetic Plains. Energy 116, 293-305 (2016).

15. Dass, S., Jat, M.L., Singh, K.P. \& Rai, H.K. Agro-economic analysis of maize-based cropping system in India. Indian J. Fertil. 4, 49-62 (2008).

16. Hobbs, P.R., Sayre, K. \& Gupta, R. The role of conservation agriculture in sustainable agriculture. Philos. Trans. R. Soc. Lond. Ser. B. 363, 543-555 (2008).

17. Gathala, M.K. et al. Effect of tillage and crop establishment methods on physical properties of a medium-textured soil under a sevenyear rice-wheat rotation. Soil Sci. Soc. Am. J. 75, 1851-1862 (2011).

18. Saharawat, Y.S. et al. Simulation of resource-conserving technologies on productivity, income and greenhouse gas $\left(\mathrm{G}_{\mathrm{HG}}\right)$ emission in rice-wheat system. J. Soil Sci. Environ. Manage. 3, 9-22 (2012).

19. Jat, H.S. et al. Designing profitable, resource-use efficient and environmentally sound cereal-based systems for the Western Indo Gangetic plains. Sci. Rep. 10, 19267 (2020).

20. Pooniya, V. et al. Six years of conservation agriculture and nutrient management in maize-mustard rotation: Impact on soil properties, system productivity and profitability. Field Crops Res. 260, 108002 (2021).

21. Kumar, D. \& Shivay, Y.S. Integrated crop management. National Science Digital Library, NISCAIR, New Delhi, http: // nsdl. niscair. res. in/ jspui/ handle/123456789/679 (2008).

22. Suhas, P.W., Anantha, K.H. \& Garg, K.K. Soil properties, crop yield, and economics under integrated crop management practices in Karnataka, Southern India. World Develop. 20, 1-19 (2017).

23. Wang, D., Haung, J., Nie, L. \& Wang, F. ICM practices for maximizing grain yield of doubled-season rice crop. Sci. Rep. 7, 38982 (2017).

24. Lancon, J. et al. An improved methodology for integrated crop management systems. Agron. Sustain. Dev. 27, 101 (2007).

25. Hawes, C. et al. Plant responses to an integrated cropping system designed to maintain yield whilst enhancing soil properties and biodiversity. Agron. 8, 229 (2018).

26. Ladha, J.K. et al. Productivity trends in intensive rice-wheat cropping systems in Asia. In: Ladha, J.K. et al. (Eds.), Improving the productivity and sustainability of rice-wheat systems: Issues and impacts. ASA Spec. Publ. 65. ASA, CSSA, and SSA, Madison, WI. pp. 45-76 (2003).

27. Mahajan, G., Singh, K. \& Gill, M.S. Scope for enhancing and sustaining rice productivity in Punjab (food bowl of India). Afr. J. Agric. Res. 7, 5611-5620 (2012).

28. Chapagain, A. \& Hoekstra, A.Y. The blue, green and grey water footprint of rice from both a production and consumption perspective. Value of water research report 40, No. 40. Unesco-IHE Institute for Water Education (2010). 
29. Kumar, V. \& Ladha, J.K. Direct seeding of rice: recent developments and future research needs. Adv. Agron. 111, 299-360 (2011).

30. Cerdà, A. et al. Hydrological and erosional impact and farmer's perception on catch crops and weeds in citrus organic farming in Canyoles river watershed, Eastern Spain. Agric. Ecosyst. Environ. 258, 49-58 (2018).

31. Jat, R.K. et al. Seven years of conservation agriculture in a rice wheat rotation of eastern Indo Gangetic plains of south Asia: Yield trends and economic profitability. Field Crops Res. 164, 199-210 (2014).

32. Gathala, M.K. et al. Optimizing intensive cereal-based cropping systems addressing current and future drivers of agricultural change in the north-western Indo-Gangetic plains of India. Agric. Ecosys. Environ. 177, 85-97 (2013).

33. Poeplau, C., Reiter, L., Berti, A. \& Kätterer, T. Qualitative and quantitative response of soil organic carbon to 40 years of crop residue incorporation under contrasting nitrogen fertilization regimes. Soil Res. 55, 1-9 (2017).

34. Wei, W. et al. Effects of combined application of organic amendments and fertilizers on crop yield and soil organic matter: An integrated analysis of long-term experiments. Agric. Ecosyst. Environ. 225, 86-92 (2016).

35. Hijbeek, R. et al. Do organic inputs matter: A meta-analysis of additional yield effects for arable crops in Europe. Plant Soil 411, 293303 (2017).

36. Zhang, S. et al. Arbuscular mycorrhizal fungi increase grain yields: a meta-analysis. New Phytologist. 222, 543-555 (2019).

37. Govindarajulu, M. et al. Nitrogen transfer in the arbuscular mycorrhizal symbiosis. Nature 435, 819-823 (2005).

38. Smith, S.E. \& Read, D.J. Mycorrhizal symbiosis. San Diego, CA, USA: Academic Press (2008).

39. Lehmann, A. et al. Arbuscular mycorrhizal influence on zinc nutrition in crop plants - a meta-analysis. Soil Biol. Biochem. 69, 123-131 (2014).

40. Pooniya, V., Palta, J.A., Chen, Y., Delhaize, E. \& Siddique, K.H.M. Impact of the TaMATE1B gene on above and below-ground growth of durum wheat grown on an acid and $\mathrm{Al}^{3+}$-toxic soil. Plant Soil 447, 73-84 (2020).

41. Hoeksema, J.D. et al. A meta-analysis of context-dependency in plant response to inoculation with mycorrhizal fungi. Ecol. Lett. 13, 394-407 (2010).

42. Pellegrino, E. et al. Responses of wheat to arbuscular mycorrhizal fungi: a meta-analysis of field studies from 1975 to 2013 . Soil Biol. Biochem. 84, 210-217 (2015).

43. Chandrasekaran, M. et al. A meta-analysis of arbuscular mycorrhizal effects on plants grown under salt stress. Mycorrhiza 24, 611-625 (2014).

44. Jayne, B. \& Quigley, M. Influence of arbuscular mycorrhiza on growth and reproductive response of plants under water deficit: a metaanalysis. Mycorrhiza 24, 109-119 (2014).

45. Sarkar, S. et al. Management of crop residues for improving input use efficiency and agricultural sustainability. Sustainability 12 , 9808 (2020).

46. Govaerts, B. et al. Infiltration, soil moisture, root rot and nematode populations after 12 years of different tillage, residue and crop rotation managements. Soil Till. Res. 94, 209-219 (2007).

47. Thierfelder, C. \& Wall, P.C. Effects of conservation agriculture techniques on infiltration and soil water content in Zambia and Zimbabwe. Soil Till. Res. 105, 217-227 (2009).

48. Pooniya, V. et al. Long-term conservation agriculture and best nutrient management improves productivity and profitability coupled with soil properties of a maize-chickpea rotation. Sci. Rep. 11, 10386 (2021).

49. Nawaz, A. et al. Comparison of conventional and conservation rice-wheat systems in Punjab, Pakistan. Soil Till. Res. 169, 35-43 (2017).

50. Dubey, R. et al. Impact of terminal heat stress on wheat yield in India and options for adaptation. Agric. Syst. 181, 102826 (2020).

51. Gathala, M.K. et al. Conservation agriculture-based tillage and crop establishment options can maintain farmers' yields and increase profits in South Asia's rice-maize systems: evidence from Bangladesh. Field Crops Res. 172, 85-98 (2015).

52. Thomas, G.A., Dalal, R.C. \& Standley, J. No-till effects on organic matter, pH and cation exchange capacity and nutrient distribution in a Luvisol in the semi-arid subtropics. Soil Till. Res. 94, 295-304 (2007).

53. Wang, W.J. et al. Soil Carbon sequestration and density distribution in a vertosol under different farming practices. Aust. J. Soil Res. 42(8), 875-882 (2004).

54. Li, Y. et al. Conservation agriculture practices increase soil microbial biomass carbon and nitrogen in agricultural soils: A global metaanalysis. Soil Biol. Biochem. 121, 50-58 (2018).

55. Mondal, S. et al. Conservation agriculture had a strong impact on the sub-surface soil strength and root growth in wheat after a 7-year transition period. Soil Till. Res. 195, 104385 (2019).

Page $12 / 19$ 
56. Liu, C. et al. Effects of straw carbon input on carbon dynamics in agricultural soils: a meta-analysis. Glob. Change Biol. 20, 1366-1381 (2014).

57. Kallenbach, C. \& Grandy, A.S. Controls over soil microbial biomass responses to carbon amendments in agricultural systems: a metaanalysis. Agric. Ecosyst. Environ. 144, 241-252 (2011).

58. Zhang, Q. et al. Effects of long-term fertilization management practices on soil microbial biomass in China's cropland: a meta-analysis. Agron. J. 109, 1183-1195 (2017).

59. Pooniya, V., Shivay, Y.S., Rana, A., Nain, L. \& Prasanna, R. Enhancing soil nutrient dynamics and productivity of Basmati rice through residue incorporation and zinc fertilization. Eur. J. Agron. 41, 28-37 (2012).

60. Campbell, $\mathrm{C}$. et al. Effect of crop management on $\mathrm{C}$ and $\mathrm{N}$ in long-term crop rotations after adopting no-tillage management: comparison of soil sampling strategies. Can. J. Soil Sci. 78, 155-162 (1998).

61. Wolinska, A. \& Stepniewska, Z. Dehydrogenase activity in the soil environment. In: Canuto R.A. (ed.): Dehydrogenases. Intech, Rijeka. http://www.ebook3000.com (2012).

62. Singh, G. et al. Effect of organics, biofertilizers and crop residue application on soil microbial activity in rice-wheat and rice-wheat mungbean cropping systems in the Indo-Gangetic plains, Cogent. Geoscience 1(1), 1085296 (2015).

63. Masciandaro, G. et al. Kinetic parameters of dehydrogenase in the assessment of the response of soil to vermicompost and inorganic fertilisers. Biol. Fertil. Soils 32(6), 479-483 (2000).

64. Dhull, S.K. et al. Microbial biomass carbon and microbial activities of soils receiving chemical fertilizers and organic amendments. Arch. Agron. Soil Sci. 50, 641-647 (2004).

65. Nath, C.P. et al. Impact of variable tillage-based residue management and legume-based cropping for seven years on enzymes activity, soil quality index and crop productivity in rice ecology. Environ. Sust. Indicat. 10, 100107 (2021).

66. Borase, D.N. et al. Long-term impact of diversified crop rotations and nutrient management practices on soil microbial functions and soil enzymes activity. Ecol. Indicat. 114, 106322 (2020).

67. Alkorta, I. et al. Soil enzyme activities as biological indicators of soil health. Rev. Environ. Health 18, 65-73 (2003).

68. Piper, C.S. Soil and plant analysis. The University of Adelaide, Australia, 286-287 (1950).

69. Walkley, A.J. \& Black, I.A. An examination of the Degtjareff method for determination of soil organic matter and a proposed modification of the chromic acid titration method. Soil Sci. 37, 29-38 (1934).

70. Subbiah, B.V. \& Asija, G.L. A rapid procedure for estimation of the available nitrogen in soil. Curr. Sci. 25, 259-260 (1956).

71. Vance, E.D., Brookes, P.C. \& Jenkinson, D.S. An extraction method for measuring soil microbial biomass carbon. Soil Biol. Biochem. 19, 703-704 (1987).

72. Tabatabai, M.A. \& Bremner, J.M. Use of p-nitrophenyl phosphate for assay of soil phosphatase activity. Soil Biol. Biochem. 1, 301-307 (1969).

73. Casida Jr, L.E., Klein, D.A. \& Santoro, T. Soil dehydrogenase activity. Soil Sci. 93, 371-376 (1964).

74. Tabatabai, M.A. \& Bremner, J.M. Assay of urease activity in soils. Soil Biol. Biochem. 4(4), 479-487 (1972).

75. Suri, V.K. \& Choudhary, A.K. Effect of vesicular arbuscular mycorrhizal fungi and phosphorus application through soil-test crop response precision model on crop productivity, nutrient dynamics, and soil fertility in soybean-wheat-soybean crop sequence in an acidic Alfisol. Commun. Soil Sci. Plant Ana. 44, 2032-2041 (2013).

76. Prasad, R. et al. Learning by Doing Exercise in Soil Fertility (A Practical Manual for Soil Fertility), Division of Agronomy. Indian Agricultural Research Institute, New Delhi, p. 68 (2006).

77. Singh, R.P. et al. Towards Sustainable Dryland Agricultural Practices (CRIDA, 1990).

78. Wanjari et al. Sustainable yield index: An approach to evaluate the sustainability of long-term intensive cropping systems in India. $J$. Sustain. Agric. 24(4), 39-56 (2004).

79. Gomez, K.A. \& Gomez, A.A. Statistical Procedures for Agricultural Research. An International Rice Research Institute Book, second ed. Wiley-Inter-Science Publication, John Wiley \& Sons, New York (1984).

\section{Tables}

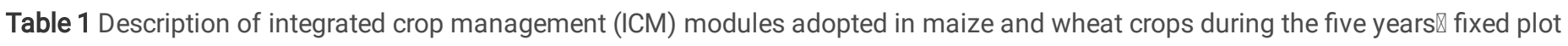
experimentation. 


\begin{tabular}{|c|c|c|}
\hline Treatment notations & Maize & Wheat \\
\hline $\mathrm{ICM}_{1}$ & $\mathrm{CT}_{\mathrm{FB}}+100 \% \mathrm{R}_{\mathrm{DF}}$ & $\mathrm{CT}_{\mathrm{FB}}+100 \% \mathrm{R}_{\mathrm{DF}}$ \\
\hline $\mathrm{ICM}_{2}$ & $\mathrm{CT}_{\mathrm{FB}}+75 \% \mathrm{R}_{\mathrm{DF}}+\mathrm{A}_{\mathrm{MF}}+\mathrm{L}_{\mathrm{BFs}}$ & $\mathrm{CT}_{\mathrm{FB}}+75 \% \mathrm{R}_{\mathrm{DF}}+\mathrm{A}_{\mathrm{MF}}+\mathrm{L}_{\mathrm{BFs}}$ \\
\hline $\mathrm{ICM}_{3}$ & $\mathrm{CT}_{\mathrm{RB}}+100 \% \mathrm{R}_{\mathrm{DF}}$ & $\mathrm{CT}_{\mathrm{RB}}+100 \% \mathrm{R}_{\mathrm{DF}}$ \\
\hline $\mathrm{ICM}_{4}$ & $C T_{R B}+75 \% R_{D F}+A_{M F}+L_{B F s}$ & $\mathrm{CT}_{\mathrm{RB}}+75 \% \mathrm{R}_{\mathrm{DF}}+\mathrm{A}_{\mathrm{MF}}+\mathrm{L}_{\mathrm{BFs}}$ \\
\hline $\mathrm{ICM}_{5}$ & $\mathrm{ZT}_{\mathrm{M}}+\mathrm{W}_{\mathrm{R}}+100 \% \mathrm{R}_{\mathrm{DF}}$ & $\mathrm{ZT}_{\mathrm{W}}+\mathrm{M}_{\mathrm{R}}+100 \% \mathrm{R}_{\mathrm{DF}}$ \\
\hline $\mathrm{ICM}_{6}$ & $\mathrm{ZT}_{\mathrm{M}}+\mathrm{W}_{\mathrm{R}}+75 \% \mathrm{R}_{\mathrm{DF}}+\mathrm{A}_{\mathrm{MF}}+\mathrm{L}_{\mathrm{BFs}}$ & $Z T_{W}+M_{R}+75 \% R_{D F}+A_{M F}+L_{B F s}$ \\
\hline $\mathrm{ICM}_{7}$ & $\mathrm{ZT}_{\mathrm{RB}}+\mathrm{W}_{\mathrm{R}}+100 \% \mathrm{R}_{\mathrm{DF}}$ & $\mathrm{ZT}_{\mathrm{RB}}+\mathrm{M}_{\mathrm{R}}+100 \% \mathrm{R}_{\mathrm{DF}}$ \\
\hline $\mathrm{ICM}_{8}$ & $\mathrm{ZT}_{\mathrm{RB}}+\mathrm{W}_{\mathrm{R}}+75 \% \mathrm{R}_{\mathrm{DF}}+\mathrm{A}_{\mathrm{MF}}+\mathrm{L}_{\mathrm{BFS}}$ & $\mathrm{ZT}_{\mathrm{RB}}+\mathrm{M}_{\mathrm{R}}+75 \% \mathrm{R}_{\mathrm{DF}}+\mathrm{A}_{\mathrm{MF}}+\mathrm{L}_{\mathrm{BFs}}$ \\
\hline
\end{tabular}

${ }^{\#} I C M_{182}=$ conventional flatbed maize \& wheat $\left(C T_{F B}\right) ; I C M_{3 \& 4}=$ conventional raised bed maize \& wheat $\left(C T_{R B}\right) ; I C M_{5 \& 6}=$ zero-till $(Z T)$ flatbed maize with wheat residue at $\sim 3 \mathrm{Mg} \mathrm{ha}^{-1}\left(\mathrm{ZT}_{\mathrm{M}}+\mathrm{W}_{\mathrm{R}}\right)$ \& $\mathrm{ZT}$ wheat with maize residue at $\sim 5 \mathrm{Mg} \mathrm{ha}^{-1}\left(\mathrm{ZT}_{\mathrm{W}}+\mathrm{M}_{\mathrm{R}}\right)$, and ICM $788=\mathrm{ZT}$ raised bed maize with wheat residue $\left(Z T_{R B}+W_{R}\right)$ \& $Z T$ wheat with maize residue $\left(Z T_{R B}+M_{R}\right)$. ${ }^{\#} R_{D F}=$ recommended fertilizers for maize / wheat 150:26.2:50 / 120:26:33 NPK kg ha-1 $; L_{B F s}=$ NPK liquid bio-fertilizer; $A_{M F}=$ arbuscular mycorrhizal fungi.

\#Integrated weed management (maize): ICM 1 -4 $=$ atrazine-pre-emergence $\left(P_{E}\right)$ fb 1 hand weeding $\left(H_{W}\right)$ mulch; $I_{5-8}=$ glyphosate-preplant $\left(P_{P}\right)+$ atrazine $-P_{E} f b I H_{W}$ mulch. I $I_{W M}$ (wheat): $I C M_{1-4}=$ sulfosulfuron 75 + metsulfuran-methyl (total) $-P_{O E} ; I C_{5-8}=$ glyphosate- $P_{P} f b$ pendimethalin- $P_{E} \&$ total $P^{O E}$. \#Need-based integrated pest management $\left(I_{P M}\right)$ and disease management $\left(I_{D M}\right)$ were followed in all the $I_{C M}$ modules.

Table 2 Five years' pooled grain and stover / straw $\left(\mathrm{Mg} \mathrm{ha}^{-1}\right)( \pm$ S.D.) yields of maize-wheat rotation under different ICM modules. Means followed by a similar lowercase letters within a column are not significantly different at $p<0.05$ according to Tukey's HSD test.

\begin{tabular}{|lllll|}
\hline Treatment & Maize & \multicolumn{3}{l|}{ Wheat } \\
\cline { 2 - 5 } & Grain & Stover & Grain & Straw \\
\hline$I C M_{1}$ & $4.1^{\mathrm{b}} \pm 0.33$ & $7.2^{\mathrm{b}} \pm 0.52$ & $4.4^{\mathrm{a}} \pm 0.16$ & $6.7^{\mathrm{a}} \pm 0.20$ \\
\hline $\mathrm{ICM} M_{2}$ & $4.1^{\mathrm{b}} \pm 0.11$ & $7.1^{\mathrm{b}} \pm 0.40$ & $4.3^{\mathrm{a}} \pm 0.23$ & $6.7^{\mathrm{a}} \pm 0.39$ \\
\hline$I C M_{3}$ & $4.4^{\mathrm{ab}} \pm 0.27$ & $7.8^{\mathrm{ab}} \pm 0.21$ & $4.3^{\mathrm{a}} \pm 0.20$ & $6.7^{\mathrm{a}} \pm 0.39$ \\
\hline$I C M_{4}$ & $4.2^{\mathrm{ab}} \pm 0.11$ & $7.9^{\mathrm{ab}} \pm 0.26$ & $4.3^{\mathrm{a}} \pm 0.30$ & $6.6^{\mathrm{a}} \pm 0.50$ \\
\hline $\mathrm{ICM}_{5}$ & $4.8^{\mathrm{ab}} \pm 0.35$ & $8.1^{\mathrm{ab}} \pm 0.45$ & $4.8^{\mathrm{a}} \pm 0.19$ & $7.3^{\mathrm{a}} \pm 0.09$ \\
\hline $\mathrm{ICM}_{6}$ & $4.6^{\mathrm{ab}} \pm 0.22$ & $7.9^{\mathrm{ab}} \pm 0.43$ & $4.8^{\mathrm{a}} \pm 0.35$ & $7.2^{\mathrm{a}} \pm 0.57$ \\
\hline$I C M_{7}$ & $5.2^{\mathrm{a}} \pm 0.15$ & $8.7^{\mathrm{a}} \pm 0.39$ & $4.9^{\mathrm{a}} \pm 0.14$ & $7.3^{\mathrm{a}} \pm 0.08$ \\
\hline$I C M_{8}$ & $5.1^{\mathrm{a}} \pm 0.19$ & $8.6^{\mathrm{a}} \pm 0.16$ & $4.8^{\mathrm{a}} \pm 0.11$ & $7.7^{\mathrm{a}} \pm 0.04$ \\
\hline
\end{tabular}

${ }^{\#} \mathrm{ICM}_{1 \& 2}$ = conventional flatbed maize \& wheat $\left(\mathrm{CT}_{\mathrm{FB}}\right) ; \mathrm{ICM}_{3 \& 4}$ = conventional raised bed maize \& wheat $\left(\mathrm{CT}_{\mathrm{RB}}\right) ; \mathrm{ICM}_{5 \& 6}=$ zero-till $(\mathrm{ZT})$ flatbed maize with wheat residue at $\sim 3 \mathrm{Mg} \mathrm{ha}^{-1}\left(\mathrm{ZT}_{\mathrm{M}}+\mathrm{W}_{\mathrm{R}}\right)$ \& $\mathrm{ZT}$ wheat with maize residue at $\sim 5 \mathrm{Mg} \mathrm{ha}^{-1}\left(\mathrm{ZT}_{\mathrm{W}}+\mathrm{M}_{\mathrm{R}}\right)$, and $\mathrm{ICM}_{7 \& 8}=\mathrm{ZT}$ raised bed maize with wheat residue $\left(Z T_{R B}+W_{R}\right)$ \& $Z T$ wheat with maize residue $\left(Z T_{R B}+M_{R}\right)$. ${ }^{\#} R_{D F}=$ recommended fertilizers for maize / wheat 150:26.2:50 / 120:26:33 NPK kg ha-1 $; L_{B F s}=$ NPK liquid bio-fertilizer; $A_{M F}=$ arbuscular mycorrhizal fungi. 
Table 3 Five years' trend of system productivity $\left(\mathrm{Mg} \mathrm{ha}^{-1}\right)\left( \pm\right.$ S.D.) in terms of maize grain equivalent yield $\left(\mathrm{M}_{\mathrm{GEY}}\right)$ of maize-wheat rotation under different ICM modules. Means followed by a similar lowercase letters within a column are not significantly different at $p<0.05$ according to Tukey's HSD test.

\begin{tabular}{llllll} 
Treatment & \multicolumn{5}{l}{ System maize grain equivalents $\left(\mathrm{M}_{\mathrm{GEY}}\right)$} \\
\cline { 2 - 6 } & $2015-16$ & $2016-17$ & $2017-18$ & $2018-19$ & $2019-20$ \\
\hline $\mathrm{ICM}_{1}$ & $8.5^{\mathrm{a}} \pm 0.94$ & $9.9^{\mathrm{a}} \pm 0.68$ & $8.7^{\mathrm{bcd}} \pm 0.25$ & $9.3^{\mathrm{bc}} \pm 0.65$ & $9.7^{\mathrm{bc}} \pm 0.54$ \\
\hline $\mathrm{ICM}_{2}$ & $9.6^{\mathrm{a}} \pm 0.95$ & $9.2^{\mathrm{a}} \pm 1.01$ & $8.4^{\mathrm{d}} \pm 0.58$ & $9.0^{\mathrm{c}} \pm 0.63$ & $9.1^{\mathrm{c}} \pm 0.53$ \\
$\mathrm{ICM}_{3}$ & $10.5^{\mathrm{a}} \pm 0.21$ & $9.1^{\mathrm{a}} \pm 1.38$ & $8.6^{\mathrm{cd}} \pm 0.30$ & $9.5^{\mathrm{bc}} \pm 0.23$ & $9.8^{\mathrm{bc}} \pm 1.53$ \\
\hline $\mathrm{ICM}_{4}$ & $9.6^{\mathrm{a}} \pm 0.80$ & $9.7^{\mathrm{a}} \pm 1.09$ & $8.6^{\mathrm{dd}} \pm 0.36$ & $9.7^{\mathrm{bc}} \pm 0.26$ & $8.7^{\mathrm{c}} \pm 0.90$ \\
$\mathrm{ICM}_{5}$ & $9.7^{\mathrm{a}} \pm 1.36$ & $9.8^{\mathrm{a}} \pm 1.45$ & $10.3^{\mathrm{ab}} \pm 1.11$ & $11.4^{\mathrm{a}} \pm 0.62$ & $10.9^{\mathrm{ab}} \pm 0.71$ \\
\hline $\mathrm{ICM}_{6}$ & $10.0^{\mathrm{a}} \pm 1.95$ & $8.8^{\mathrm{a}} \pm 1.16$ & $10.1^{\mathrm{ab}} \pm 0.70$ & $10.8^{\mathrm{ab}} \pm 0.55$ & $11.0^{\mathrm{ab}} \pm 0.66$ \\
\hline $\mathrm{ICM}_{7}$ & $10.1^{\mathrm{a}} \pm 0.66$ & $10.2^{\mathrm{a}} \pm 0.66$ & $10.8^{\mathrm{a}} \pm 0.83$ & $11.5^{\mathrm{a}} \pm 0.45$ & $11.8^{\mathrm{a}} \pm 1.15$ \\
\hline $\mathrm{ICM}_{8}$ & $10.2^{\mathrm{a}} \pm 1.50$ & $10.0^{\mathrm{a}} \pm 0.14$ & $10.0^{\mathrm{abc}} \pm 0.51$ & $11.6^{\mathrm{a}} \pm 0.64$ & $11.7^{\mathrm{a}} \pm 1.03$
\end{tabular}

${ }^{\#} I_{C M} M_{182}=$ conventional flatbed maize \& wheat $\left(C T_{F B}\right) ; I C M_{3 \& 4}=$ conventional raised bed maize \& wheat $\left(C_{R B}\right) ; I_{5} M_{5 \& 6}=$ zero-till $(Z T)$ flatbed maize with wheat residue at $\sim 3 \mathrm{Mg} \mathrm{ha}^{-1}\left(\mathrm{ZT}_{\mathrm{M}}+\mathrm{W}_{\mathrm{R}}\right)$ \& $\mathrm{ZT}$ wheat with maize residue at $\sim 5 \mathrm{Mg} \mathrm{ha}^{-1}\left(\mathrm{ZT}_{\mathrm{W}}+\mathrm{M}_{\mathrm{R}}\right)$, and ICM $\mathrm{I}_{788}=\mathrm{ZT}$ raised bed maize with wheat residue $\left(Z T_{R B}+W_{R}\right)$ \& $Z T$ wheat with maize residue $\left(Z T_{R B}+M_{R}\right) \cdot{ }^{\#} R_{D F}=$ recommended fertilizers for maize / wheat 150:26.2:50 / 120:26:33 NPK kg ha-1 $; L_{B F s}=$ NPK liquid bio-fertilizer; $A_{M F}=$ arbuscular mycorrhizal fungi.

Table 4 Effect of different ICM modules on soil dehydrogenase activity $\left(\mathrm{S}_{\mathrm{DH}}\right)$, alkaline phosphatase $\left(\mathrm{S}_{\mathrm{AP}}\right)$ and urease $\left(\mathrm{U}_{\mathrm{RE}}\right)$ at the flowering of $5^{\text {th }}$ season wheat under $\mathrm{M}_{\mathrm{WR}}$. Means followed by a similar lowercase letters within a column are not significantly different at $p<0.05$ according to Tukey's HSD test.

\begin{tabular}{|c|c|c|c|c|c|c|c|c|c|c|}
\hline \multirow[t]{2}{*}{ Treatment } & \multicolumn{3}{|c|}{$\begin{array}{l}S_{D H} \\
\left(\mu g \text { TPF g }^{-1} \text { fresh soil } d^{-1}\right)\end{array}$} & \multicolumn{4}{|c|}{$\begin{array}{l}S_{A P} \\
\left(\mu g \text { p-NP g }{ }^{-1} \text { soil h}^{-1}\right)\end{array}$} & \multicolumn{3}{|c|}{$\begin{array}{l}\mathrm{U}_{\mathrm{RE}} \\
\left(\mu \mathrm{g} \mathrm{NH} \mathrm{H}_{4}-\mathrm{N}^{-1} \text { soil } \mathrm{h}^{-1}\right)\end{array}$} \\
\hline & $\begin{array}{l}0.0- \\
0.05 \\
\mathrm{~m}\end{array}$ & $\begin{array}{l}0.05- \\
0.15 \\
\mathrm{~m}\end{array}$ & $\begin{array}{l}0.15-0.30 \\
\mathrm{~m}\end{array}$ & $0.0-0.05 \mathrm{~m}$ & n & $0.05-0.15 \mathrm{~m}$ & $0.15-0.30 \mathrm{~m}$ & $0.0-0.05 \mathrm{~m}$ & $0.05-0.15 \mathrm{~m}$ & $0.15-0.30 \mathrm{~m}$ \\
\hline $\mathrm{ICM}_{1}$ & $58.3^{c}$ & & $.1^{\mathrm{cd}}$ & $13.2^{\mathrm{ab}}$ & $54.3^{d}$ & $44.6^{b c}$ & $27.1^{\mathrm{a}}$ & $14.2^{\mathrm{c}}$ & $11.8^{\mathrm{c}}$ & $7.6^{\mathrm{a}}$ \\
\hline $\mathrm{ICM}_{2}$ & $53.2^{d}$ & & $.0^{\mathrm{d}}$ & $13.4^{\mathrm{ab}}$ & $49.8^{d}$ & $38.9^{c}$ & $30.2^{\mathrm{a}}$ & $15.6^{b c}$ & $12.6^{\mathrm{bc}}$ & $6.5^{\mathrm{a}}$ \\
\hline $\mathrm{ICM}_{3}$ & $57.4^{\mathrm{cd}}$ & & $.5^{\mathrm{cd}}$ & $15.7^{a}$ & $61.8^{c}$ & $44.9^{b c}$ & $32.8^{\mathrm{a}}$ & $14.7^{\mathrm{c}}$ & $12.3^{b c}$ & $6.1^{\mathrm{a}}$ \\
\hline $\mathrm{ICM}_{4}$ & $62.0^{b c}$ & & $.7^{\mathrm{bc}}$ & $13.4^{\mathrm{ab}}$ & $52.9^{d}$ & $43.5^{c}$ & $28.9^{a}$ & $16.3^{\mathrm{abc}}$ & $11.7^{c}$ & $8.4^{\mathrm{a}}$ \\
\hline $\mathrm{ICM}_{5}$ & $60.9^{b c}$ & & $.5^{\mathrm{cd}}$ & $16.4^{\mathrm{a}}$ & $66.0^{\mathrm{bc}}$ & $51.9^{\mathrm{a}}$ & $30.6^{\mathrm{a}}$ & $18.5^{\mathrm{ab}}$ & $13.5^{\mathrm{abc}}$ & $8.6^{\mathrm{a}}$ \\
\hline $\mathrm{ICM}_{6}$ & $67.3^{a}$ & & $.5^{\mathrm{abc}}$ & $15.5^{\mathrm{a}}$ & $70.4^{\mathrm{ab}}$ & $56.3^{a}$ & $28.9^{a}$ & $19.4^{\mathrm{a}}$ & $14.7^{\mathrm{ab}}$ & $7.7^{a}$ \\
\hline $\mathrm{ICM}_{7}$ & $63.3^{\mathrm{ab}}$ & & $.9^{\mathrm{ab}}$ & $13.8^{\mathrm{ab}}$ & $72.0^{\mathrm{a}}$ & $51.1^{\mathrm{ab}}$ & $31.6^{\mathrm{a}}$ & $18.5^{\mathrm{ab}}$ & $13.7^{\mathrm{abc}}$ & $7.8^{\mathrm{a}}$ \\
\hline $\mathrm{ICM}_{8}$ & $65.2^{\mathrm{ab}}$ & & $7^{\mathrm{a}}$ & $11.7^{\mathrm{b}}$ & $73.6^{a}$ & $42.6^{c}$ & $31.4^{\mathrm{a}}$ & $19.5^{\mathrm{a}}$ & $16.1^{\mathrm{a}}$ & $7.7^{\mathrm{a}}$ \\
\hline
\end{tabular}

${ }^{\#} I_{C M} M_{182}=$ conventional flatbed maize \& wheat $\left(C_{F B}\right) ; I_{3} M_{3 \& 4}=$ conventional raised bed maize \& wheat $\left(C_{R B}\right) ; I C M_{5 \& 6}=$ zero-till $(Z T)$ flatbed maize with wheat residue at $\sim 3 \mathrm{Mg} \mathrm{ha}^{-1}\left(\mathrm{ZT}_{\mathrm{M}}+\mathrm{W}_{\mathrm{R}}\right)$ \& $\mathrm{ZT}$ wheat with maize residue at $\sim 5 \mathrm{Mg} \mathrm{ha}^{-1}\left(\mathrm{ZT}_{\mathrm{W}}+\mathrm{M}_{\mathrm{R}}\right)$, and ICM $\mathrm{I}_{788}=\mathrm{ZT}$ raised bed 
maize with wheat residue $\left(Z T_{R B}+W_{R}\right)$ \& $Z T$ wheat with maize residue $\left(Z T_{R B}+M_{R}\right)$. ${ }^{\#} R_{D F}=$ recommended fertilizers for maize / wheat 150:26.2:50 / 120:26:33 NPK kg ha-1; $L_{B F s}=$ NPK liquid bio-fertilizer; $A_{M F}=$ arbuscular mycorrhizal fungi.

\section{Figures}

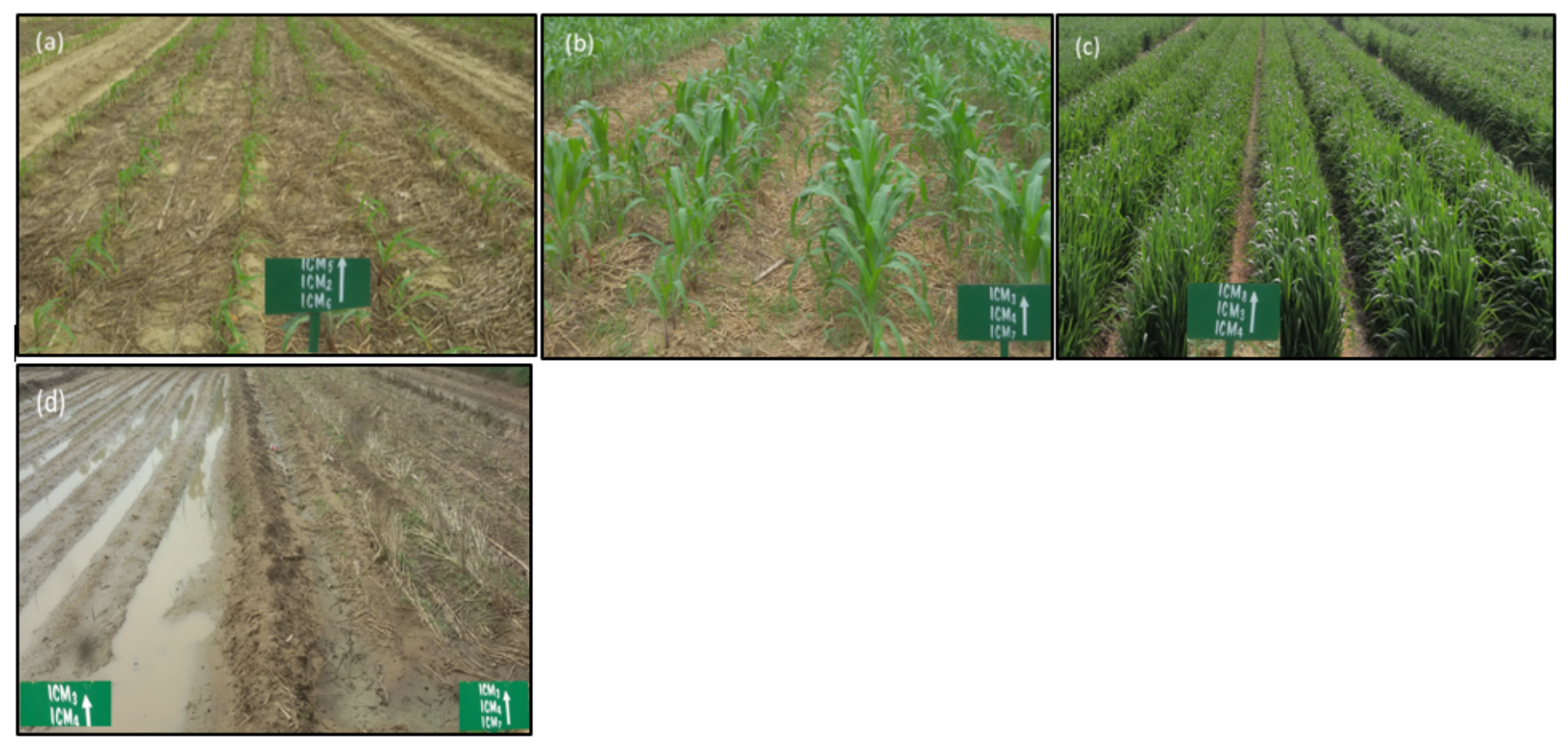

\section{Figure 1}

Initial establishment of ZT maize under residue retained CA-based ICM6 (a); $27 \mathrm{~d}$ old maize under CA-based ICM7 (b); raised bed wheat in ICM4 (c); soil conditions of CT-based ICM4 (water stagnation, left side) and CA-based residue retained ICM7 (no water stagnation, right side), photo clicked after 8 hrs of rain (d). 


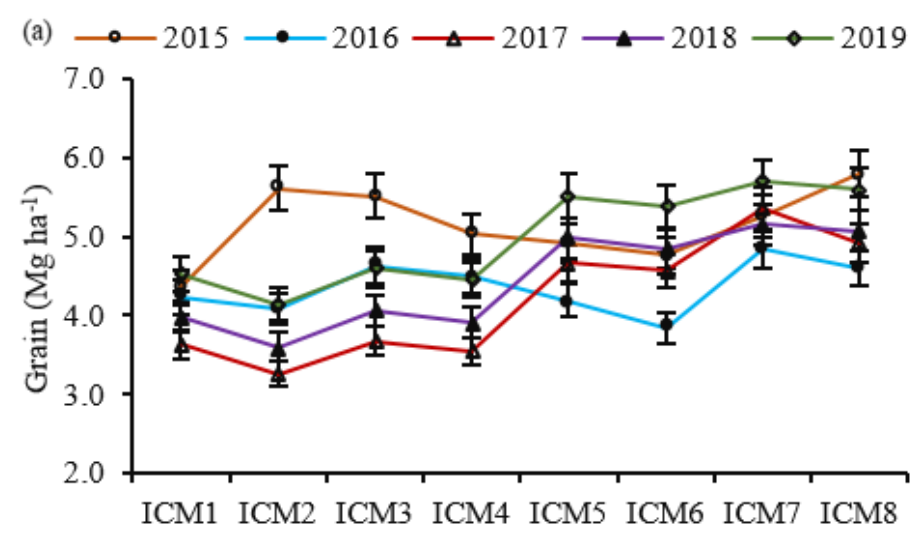

(b) $\multimap 2015 \multimap 2016 \multimap 2017 \multimap 2018 \longrightarrow 2019$
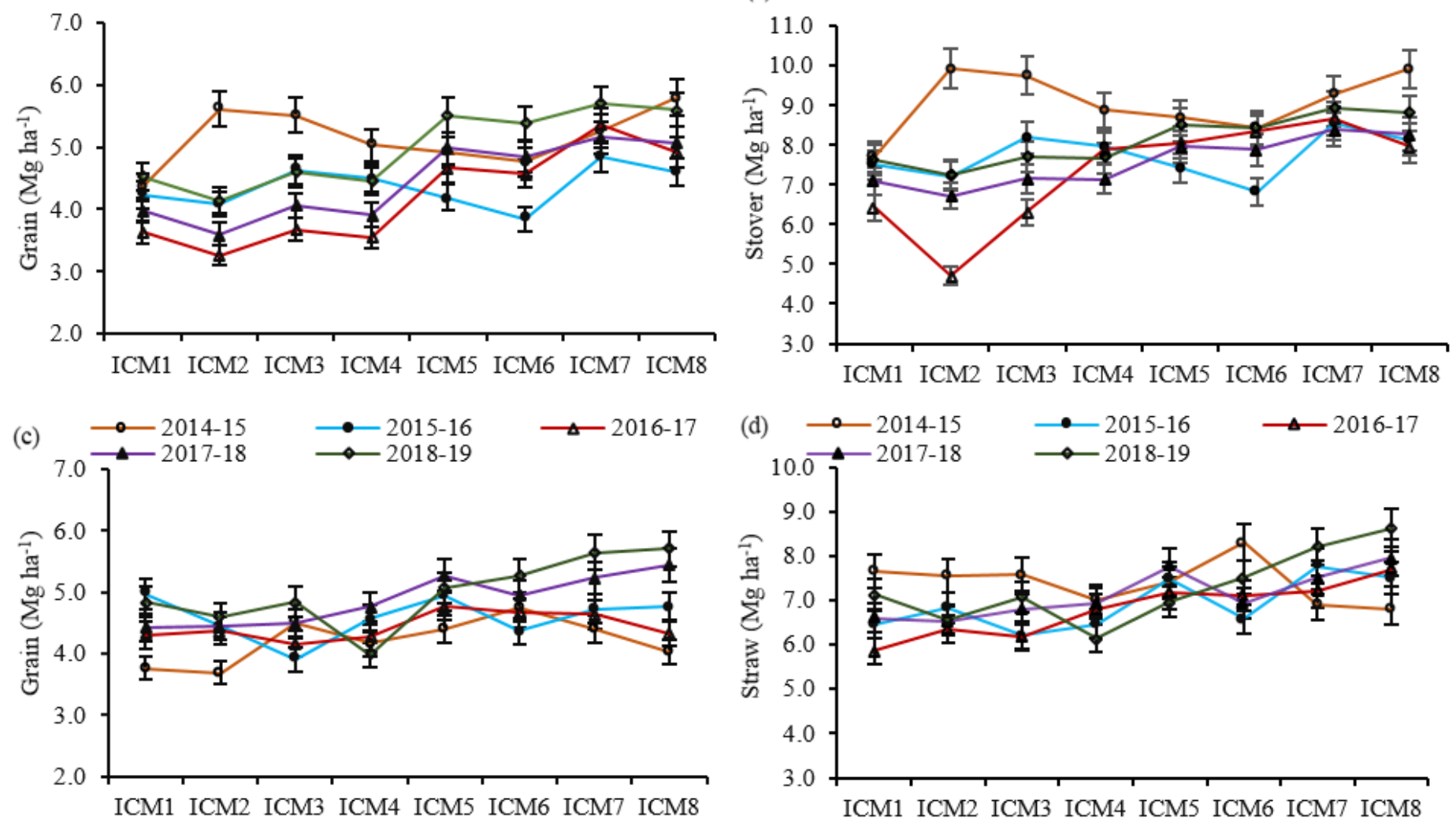

\section{Figure 2}

Five years' maize grain and stover $(a, b)$; wheat grain and straw (c, d) yield trend under different ICM modules in maize-wheat rotation. The vertical bars indicate LSD at $p=0.05$.

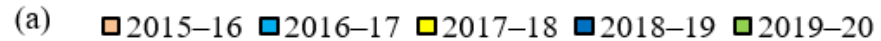

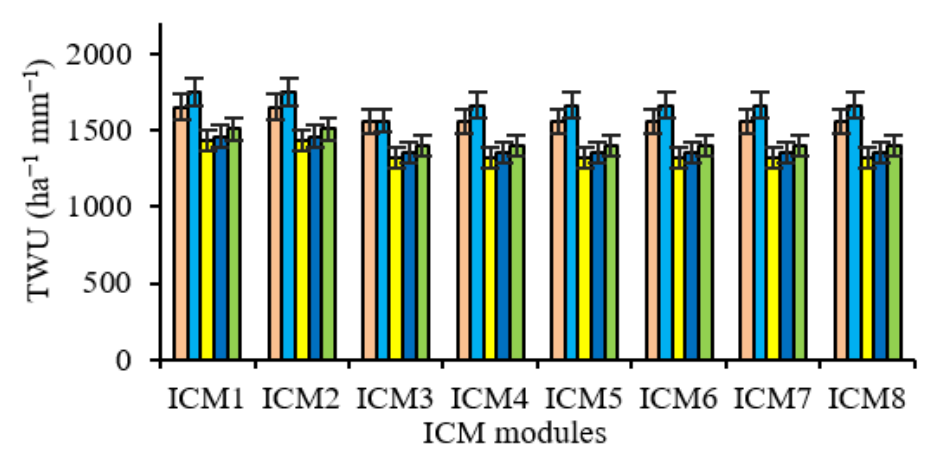

(b) प2014-15 प2015-16 व2016-17 प2017-18 $\quad$ व2018-19

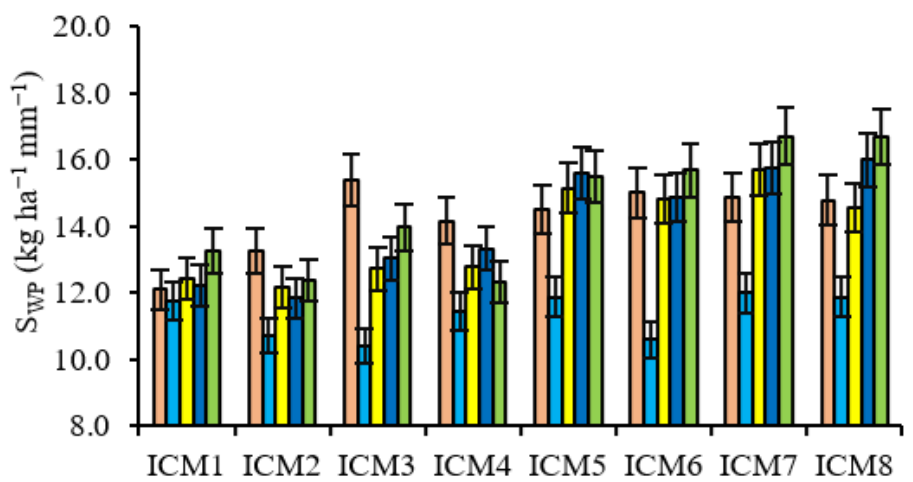

${ }^{*}$ Rainfall (mm) during cropping season: 2014-15=1022; 2015-16=1162; 2016-17=655; 2017-18=893; 2018-19=772

\section{Figure 3}

Five years' water use (a) and system water productivity (b) trend under different ICM modules in maize-wheat rotation. The vertical bars indicate LSD at $\mathrm{p}=0.05$. 

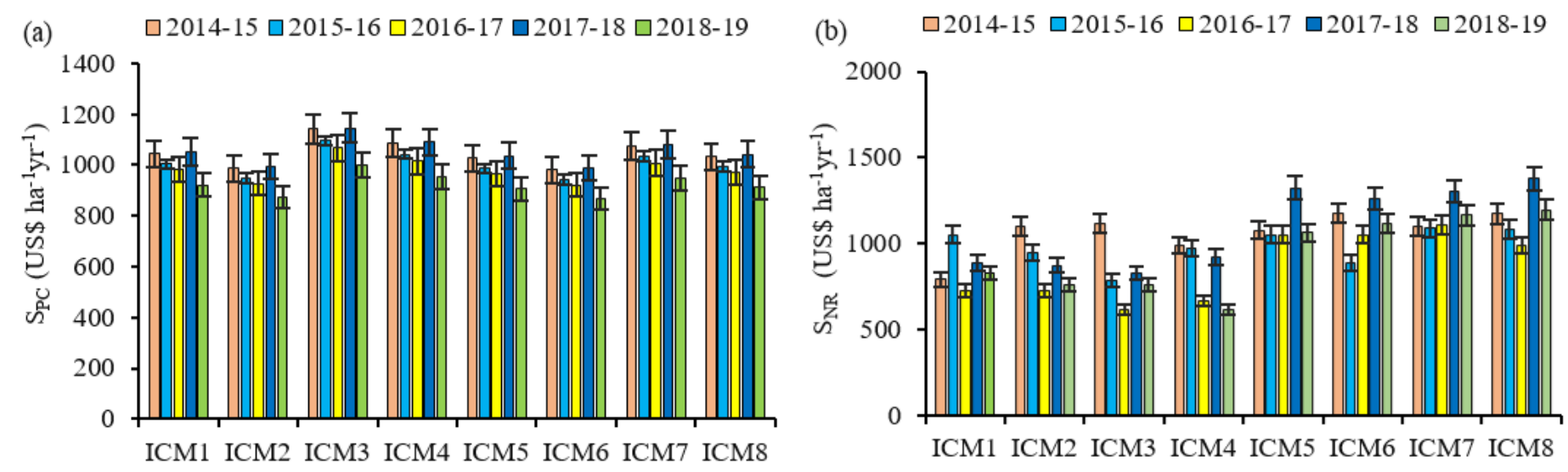

\section{Figure 4}

Five years' trend in system variable production costs (SPC) (a) and net returns (SNR) (b) under different ICM modules in the maize-wheat rotation. The vertical bars indicate LSD at $\mathrm{p}=0.05$.
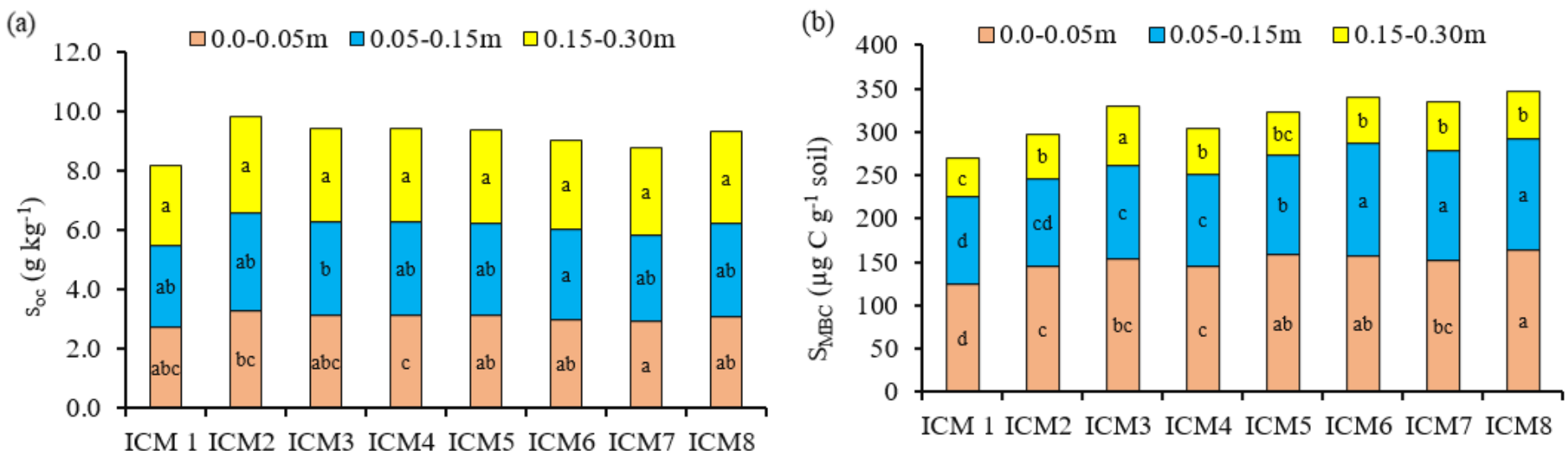

Figure 5

Effect of ICM modules on SOC (a) and soil microbial biomass carbon (SMBC) (b) at different soil depths at flowering of 5th season wheat in the maize-wheat rotation. Means followed by a similar lowercase letter within a bar are not significantly different at $p<0.05$ using Tukey's HSD test. 


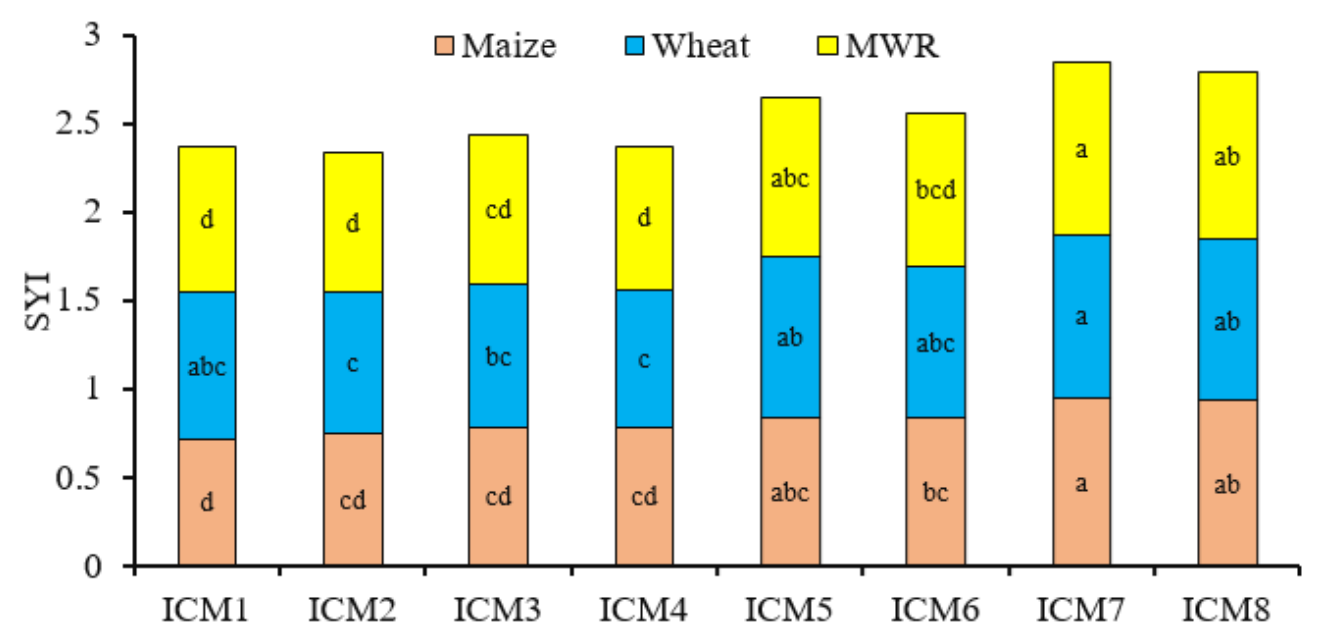

Figure 6

Effect of ICM modules on sustainable yield index (SYI) of the maize, wheat and maize-wheat rotation. Means followed by a similar lowercase letter within a bar are not significantly different at $p<0.05$ using Tukey's HSD test.

\section{Supplementary Files}

This is a list of supplementary files associated with this preprint. Click to download.

- Supplementarytable1.docx 